\title{
Taşıma Gücü ve Oturma İncelemelerinde Menard Pressiyometre Deneyinin Uygulanması: Kuloğlu HES Regülatörü Yerinde Bir Örnek Çalışma (Kars, Türkiye)
}

Application of the Menard Pressuremeter Test for the Bearing Capacity and Settlement Analysis: A Case Study at Kuloğlu Hydro-Electric Central (HEC) Regulator Site (Kars, Turkey)

\author{
Ali KAYABAŞI \\ Eskişehir Osmangazi Üniversitesi, Mühendislik Mimarlık Fakültesi, Jeoloji Mühendisliği Bölümü, \\ Meşelik, ESKIŞEHIR.

$\begin{array}{lll}\text { Geliş (received) } & : & \text { 11 Ağustos (August) } 2014 \\ \text { Düzeltme (revised) } & : & \text { 01 Ekim (October) } 2014 \\ \text { Kabul (accepted) } & : & \text { 20 Ekim (October) } 2014\end{array}$

ÖZ

Bu çalışmada Aşağı Aras Havzası hidroelektrik santrali (HES) projelerinden biri olan Kuloğlu regülatörüne ait iki sondajda yapılan Menard presiyometre deneyleri değerlendirilmiş ve Menard presiyometresi tanıtılmaya çalışılmıştır. Temel alanını kaplayan alüvyonda açılmış sondajlardan SK-1 kuyusunda 8 adet, SK-2 kuyusunda ise 12 adet presiyometre deneyi yapılmıştır. Sondaj kuyularının 20 ile 24. metrelerden sonra genişlemesi ve çökmesi nedeniyle daha derinlerde deney yapılamamıştır. Alüvyonun homojen ve heterojen olduğu kabulüyle, iki grup halinde oturma ve taşıma gücü hesaplamaları yapılmıştır. Presiyometre deneyi oturma hesaplamalarının yanı sıra temel biriminde anlık oturma hesaplaması da yapılmıştır. Deneyin uygulanabildiği derinliklerden elde edilen veriler yardımıyla yapılan hesaplama sonuçları, kabul edilebilir taşıma ve oturma sınırlar içerisindedir. Aynı hesaplamalar yardımı ile, yapı yükünden kaynaklı gerilimin derinlikle dağılımı belirlenmiştir. Yapı yükünün oluşturacağı gerilim, $48 \mathrm{~m}$ derinlikte \% 10 değerine düşmektedir. 20 ile 24. metrelerden sonra sondaj kuyularının çökmesi, genişlemesi ve yapı yükünün oluşturacağ gerilimin daha derinlere devam etmesinden dolayı alüvyonun tamamının kaldırılması önerilmiştir. Çalışmada ayrıca, Menard presiyometre deneyinin su yapısı inşaat alanlarında uygulanması sırasında karşılaşılan sorunlara da değinilmiştir.

Anahtar Kelimeler: Aras Nehri, Kuloğlu, Menard Presiyometresi, Oturma, Taşıma gücü.

A.Kayabaşı

E-Posta: akayabasi@ogu.edu.tr 
Kayabaşı

\section{ABSTRACT}

This paper deals with the short description of Menard pressuremeter and the evaluation of Menard pressuremeter tests carried out in two boreholes drilled at Kuloğlu Hydroelectric Power Plant (HPP) regulator which is one of the HPP Projects planned at Aşağl Aras basin. 8 pressuremeter tests in SK-1 borehole and 12 pressuremeter tests in SK-2 borehole were carried out at alluvium unit in the foundation site. Menard pressuremeter tests could not be carried out due to the collapsing and enlarging of the drillholes after 20 and 24 meter depths of boreholes. Two group of settlement and bearing capacity analysis were performed with the assumption of alluvium made up of homogeneous and heterogeneous. Immediate settlement computation and stress distribution analysis were also performed beside the pressuremeter analysis. The amount of settlement and bearing capacity of the alluvium are in acceptable limits in the depths of which the test could be applied. The stress from regulator load decreases to \% 10 at a depth of greater than $48 \mathrm{~m}$. Due to the collapsing-enlarging of the boreholes after 20 and $24 \mathrm{~m}$ depths and the load-related stress increase acting greater depths, the excavation of the all alluvial soils is suggested. At the end of this study, the problems arisen from application of Menard pressuremeter test for the hydraulic structures are outlined.

Key Words: Aras River, Kuloğlu, Menard Pressuremeter, Settlement, Bearing capacity.

\section{GíRiș}

Çalışma alanı, Kars'ın 87 km güneyinde, Kağızman ilçesinin yaklaşık $17 \mathrm{~km}$ güney batısında yer almaktadır (Şekil 1). Kağızman ve çevresinde Mesozoyik yaşlı birimleri, Jura-Üst Kratase yaşlı peridotitler, volkanitler, kireçtaşı olistolitleri, sedimanter kayaçlar ve intrusif kayaçlar temsil eder (MTA, 2003). Kağızman ve yöresinde Tersiyer volkanizması asidik tüflerle başlar ve daha sonra bazik lavlarla devam eder. Eski alüvyon olarak da tanımlanan taraçalar, dik yamaç eteklerinde yerçekimi ve su etkisiyle oluşmuş yığışımlar oluştururlar. Taraçalar PliyoKuvaterner yaşlıdır (Şekil 2).

Kuloğlu Regülatörü, Aşağı Aras havzası HES projelerinden birisidir. Regülatör yerini oluşturan Aras Nehri alüvyonal zeminlerinin taşıma gücünün ve oturma miktarının belirlenmesi amacıyla, çalışma alanında iki adet sondaj kuyusu açılmıştır. Sondaj kuyularında her 1.5 m'de bir deney yapma koşulu öngörülmüştür. Aras Nehri alüvyonları kötü derecelenmiş çakıl, killi çakı1 ve killi kumdan oluşmaktadır. SK-1 kuyusunda 8 adet presiyometre deneyi yap1labilirken SK-2 kuyusunda ancak 12 adet deney yapılabilmiştir. Sondaj ve presiyometre deneylerinin yapımı sırasında birçok seviyede kuyu genişlemesi ve dolgu-döküntü gibi sorunlar nedeniyle deney yapılamamıştır. SK-1 adlı kuyuda 20 m derinliğe kadar inilebilirken, SK-2 adlı kuyuda ancak 24 m'ye kadar inilebilmiştir. $\mathrm{Bu}$ metrelerden sonra kuyuların devamlı döküntü yapması ve çaplarının genişlemesi nedeniyle deneye son verilmiştir.

Presiyometre deneyi, temel alt1 zemin özelliklerini belirleyen kuyu içi yükleme deneylerinden birisidir. $\mathrm{Bu}$ deneyde temel fikir, zeminin basınç-deformasyon ilişkilerini 

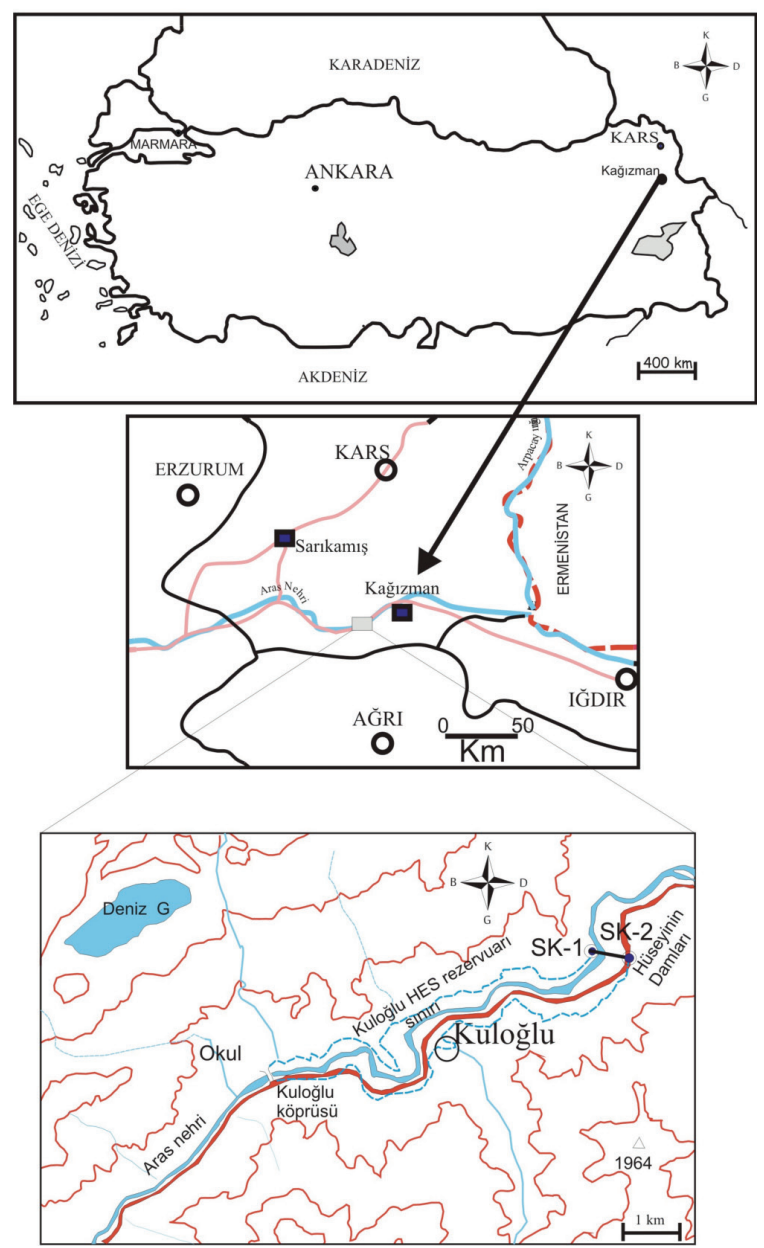

Şekil 1. Aşağ1 Aras Havzası Kuloğlu regülatörü yer bulduru haritası.

Figure 1. Location map of the Kuloğlu regülatör in the lower part of Aras Basin.

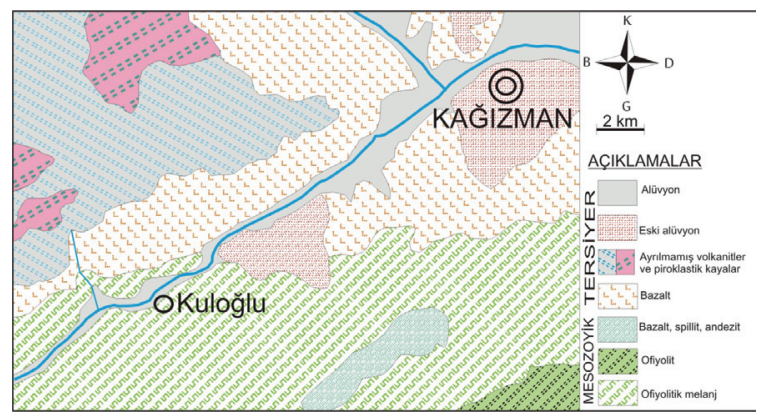

Şekil 2. Kuloğlu regülatör yeri ve çevresinin jeoloji haritas1 (MTA, 2003).

Figure 2. Geological map of the Kuloğlu regulator site and its environment (MTA,2003). ölçmek için zeminde açılan silindirik bir boşluğun genişletilmesidir (Şekil 3). Zeminin deformasyon anlayışı, 1930'lu yıllarda, Alman araştırmacı Koegler tarafından ortaya konmasına rağmen, presiyometrenin bulunuşu 1950 ortalarına rastlar. $\mathrm{Bu}$ tarihlerde $\mathrm{Dr}$. Mr. Louis Menard adlı bir araştırmacı, presiyometre deney aletini icat etmiştir. 1960'lı yılların başlarında da presiyometre cihazlarını imal etmeye başlamıştır (Baquelin vd., 1978).

Ülkemizde ilk presiyometre deneyleri 1969 yılında Devlet Su İşleri (DSI) tarafından Menard firmasından alınan G-tipi presiyometrenin kullanımıyla başlamıştır (Erdoğan, 1980). 1980'li yılların başlarında da GA-tipi presiyometre Elektrik İşleri Etüt İdaresi (EİEI) tarafından kullanılmaya başlamıştır (Şekil 4). Presiyometre deneyi, çok yumuşak zeminlerden, basınç dayanımı 20 MPa'ya kadar olan zeminlere kadar oldukça geniş bir aralıkta yer

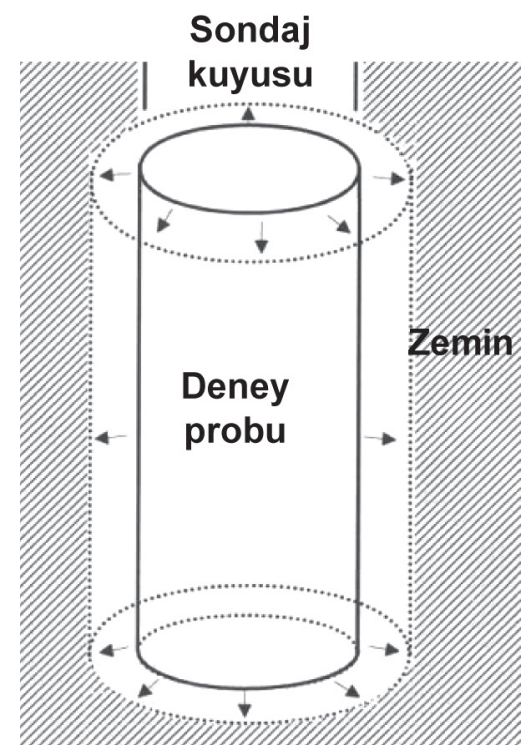

Şekil 3. Daha önce açılan silindirik bir boşlukta sondanın şişirilmesi.

Figure 3. Expanding a probe in a prebored cylindrical hole. 


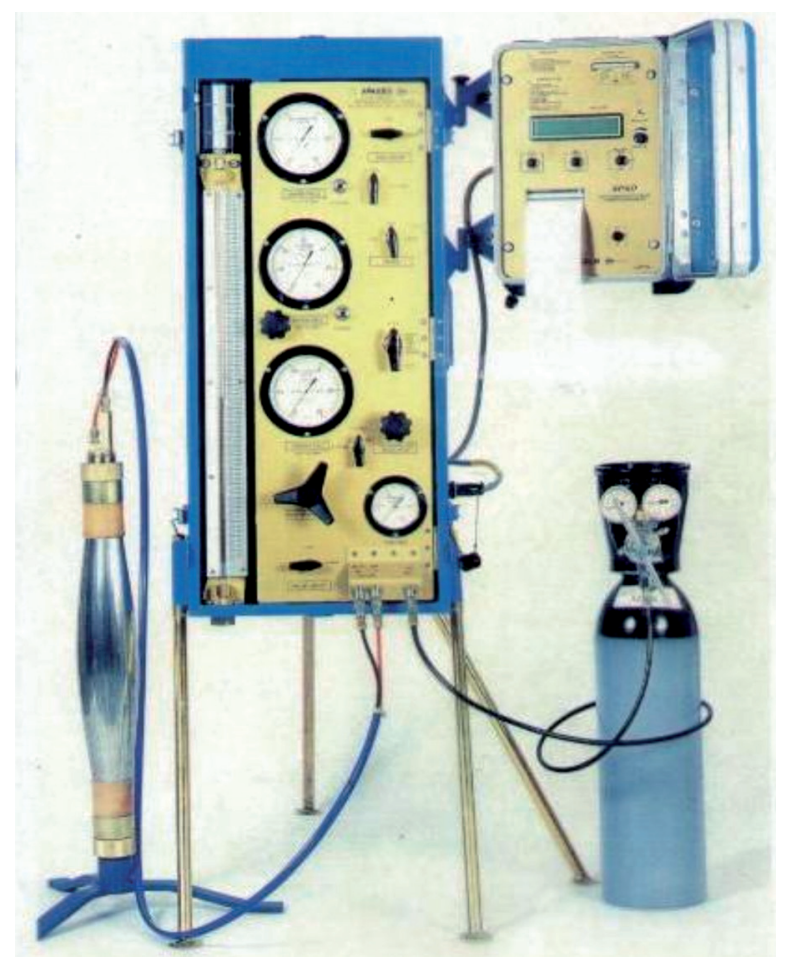

GA TIPİ PRESIYOMETRE / GA TYPE PRESSUREMETER

Şekil 4. Presiyometre modellerinden bir görünüm.

Figure 4. A view from pressuremeter types.

alan zeminler için uygulanabilmektedir. Çizelge 1 'de presiyometrenin uygulanabileceği dayanım sınırına bir yaklaşım yapılmıştır. Süreksizlik yüzeylerinin tek eksenli sıkışma dayanımına ve arazi tanımlamalarına göre sınıflandırıldığ1 tabloda zayıf kaya sınırı presiyometre deneyinin uygulanabileceği sınır olarak kabul edilebilir (ISRM, 1981).

Başarılı bir Menard presiyometre deneyi için sondaj kuyusunun uygun çapta açılması gerekir. Kuyu çapının uygun olmaması nedeniyle deney sonrasında çizilen deney eğrilerinin çoğunun başarılı olmayacağı Marnawski (2004)'te belirtilmiştir. Menard presiyometre deneyi verilerinin, diğer yerinde deney verileriyle

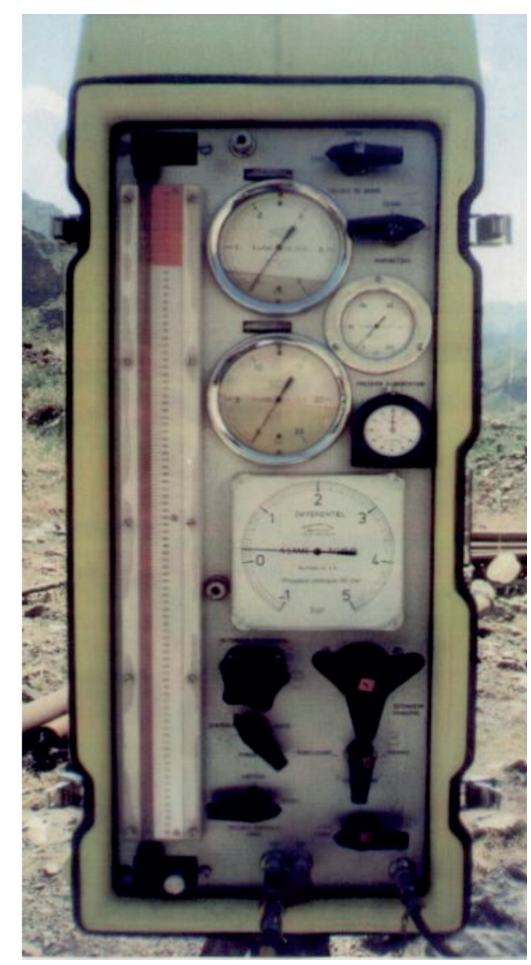

G TIPİ PRESIYOMETRE / G TYPE PRESSUREMETER

karşılaştırılarak görgül (ampirik) eşitliklerin belirlenmesi konulu makaleler literatürde yaygındır (Yağız vd., 2008; Bozbey ve Togrol, 2009; Kayabaşı, 2012). Ülkemizdeki 13 ayrı bölgede, farklı derinliklerdeki kil zeminlerde yapilan 65 adet presiyometre deneyi ve bu deneylerin taşıma gücü değerleri arasındaki değişimler Agan (2011) tarafından çalışılmıştır. Araştırmacı, killerin taşıma gücüne yönelik görgül bir eşitlik geliştirmiştir. Presiyometre deneyi, heyelan duraylılıkları ve geriye dönük analiz çalışmalarında da veri toplamak için kullanılmaktadır (Işı vd., 2008). Menard presiyometre deneyi ile hesaplanan taşıma gücü ve oturma değerlerinin diğer yaygın eşitliklerle karşılaştırılmasını Kayabaşı ve Gökçeoğlu, 
(2012) Mersin arıtma tesisi temel araştırmaları verileriyle yapmıştır. Bu çalışmada, presiyometre ile hesaplanan oturma değerinin anlık oturmaya yakınlığına dikkat çekilmiştir. Taşıma gücü eşitliklerinden, Terzaghi yöntemi (Terzaghi, 1943), Hansen yöntemi (Hansen, 1961), Meyerof yöntemi (Meyerof, 1963) ve Menard presiyometresi ile belirlenen değerler birbirine yakın çıkmıştır.

Presiyometre deneyi kuyu içinde gerçekleştirilen yerinde (In situ) bir deneydir. Çapsal olarak genişleme özelliğine sahip silindirik bir sonda kullanılarak, kuyu içinde gerçekleştirilir. Çapsal genişlemeye neden olacak basınç kuyu duvarlarına uygulanır. Esasen deney kuyu çeperlerinde yer alan zeminin gerilme-deformasyon özelliğini ortaya koyar. Deney sonunda limit basınç $\left(\mathrm{P}_{1}\right)$ ve presiyometre deformasyon modülü $\left(\mathrm{E}_{\mathrm{M}}\right)$ elde edilir. $\mathrm{P}_{1}$, sondanın hacmi, orijinal zemin boşluğu hacminin iki katına ulaşıldığı basınçtır (ASTM, 1994). $\mathrm{E}_{\mathrm{M}}$, düzeltilmiş basınç-hacim eğrisinin pseudo-elastik kısmının eğiminden hesaplanır ve deformasyon modülü olarak adlandırılır. $\mathrm{Bu}$ deney metodu, yerinde zeminin gerilmedeformasyon tepkisini verir. Elde edilen $\mathrm{P}_{1}$ ve $\mathrm{E}_{\mathrm{M}}$ değerleri, temel tasarımında ve jeoteknik analizlerde kullanılır.

Deney metodunun sonuçları, sondanın indirilmesi ve kuyunun açılması sırasındaki örselenmenin derecesine bağlıdır. Örselenme, hiçbir zaman tam olarak önlenemez ancak en aza düşürülmeye çalışılmalı, Bu konuda ASTM (1994)'e tam olarak uyulmalıdır. Örselenme, özellikle "çok yumuşak killerde" ve "çok gevşek kumlarda" kayda değer ölçülerdedir. Deney sonuçları yorumlanırken, sondaj sırasındaki şartlar da dikkate alınmalıdır.

Bir presiyometre deneyi, yaklaşık 10-15 dakika gibi kısa bir sürede yapılabilmektedir. Bunun nedeni, kilde drenajsız, kum ve çakıllı granüler zeminlerde ise ancak drenajlı deneylerin yapilabilmesidir. ASTM D4719-87, (ASTM, 1994), AFNOR NF 94-110-1 (Apageo, 2006) ve TSEV (1997-3) presiyometre ile ilgili kullanılan standartlardir.

Çizelge 1 Süreksizlik yüzeylerinin tek eksenli sıkışma dayanımına ve arazi tanımlamalarına göre sınıflandırılması (ISRM, 1981).

Table 1. Classification of discontinuity surfaces according to uniaxial compressive strength and field identification (ISRM, 1981).

\begin{tabular}{|c|c|c|c|}
\hline Simge & Tanım & Saha tanımlaması & $\begin{array}{l}\text { Tek eksenli sıkışma } \\
\text { dayanımı, } \sigma_{\mathrm{ci}}(\mathrm{MPa})\end{array}$ \\
\hline R0 & $\begin{array}{l}\text { Aşırı derecede } \\
\text { zayıf kaya }\end{array}$ & Kayanın yüzeyinde tırnak ile çentik oluşturulabilir & $0.25-1.0$ \\
\hline $\mathrm{R} 1$ & Çok zayıf kaya & Jeolog çekiciyle sert bir darbeyle ufalanan kaya, çakı ile doğranabilir. & $1.0-5.0$ \\
\hline $\boldsymbol{R 2}$ & Zayıf kaya & $\begin{array}{c}\text { Kaya, çakı ile güçlükle doğranır. Jeolog çekici ile yapılacak bir darbe } \\
\text { kayacın yüzeyinde iz bırakır. }\end{array}$ & $5.0-25$ \\
\hline $\mathrm{R} 3$ & $\begin{array}{l}\text { Orta derecede } \\
\text { sağlam kaya }\end{array}$ & $\begin{array}{c}\text { Kaya çakı ile doğranamaz. Kaya örneği, jeolog çekici ile yapılacak tek ve } \\
\text { sert bir darbeyle kırılabilir. }\end{array}$ & $25-50$ \\
\hline $\mathrm{R} 4$ & Sağlam kaya & $\begin{array}{c}\text { Kaya örneğinin kırılabilmesi için jeolog çekici ile birden fazla darbenin } \\
\text { uygulanması gerekir. }\end{array}$ & $50-100$ \\
\hline $\mathrm{R} 5$ & Çok sağlam kaya & Kaya örneğinin kırılabilmesi için jeolog çekici ile çok sayıda darbe gerekir. & $100-250$ \\
\hline R6 & $\begin{array}{l}\text { Aşırı derecede } \\
\text { sağlam kaya }\end{array}$ & Kaya örneği jeolog çekici ile sadece yontulabilir. & $>250$ \\
\hline
\end{tabular}


Kayabaşı
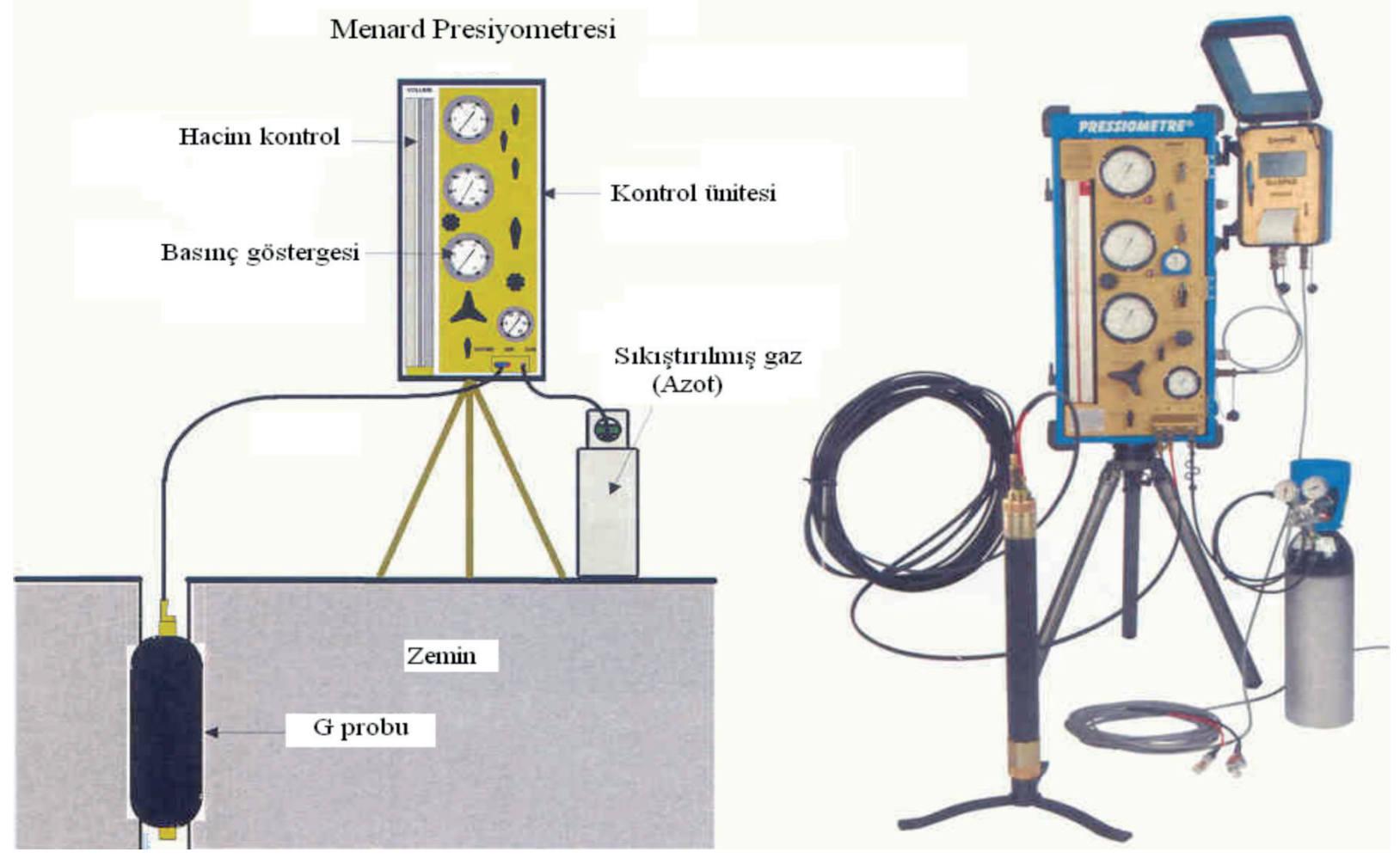

Şekil 5. G tipi presiyometre cihazı ve parçaları (Apageo, 2006).

Figure 5. G-type pressuremeter and its parts (Apageo, 2006).

Presiyometre aleti, kontrol ünitesi, silindirik sonda, iletim hortumları ve tüp olmak üzeredört ana bölümden oluşmaktadır (Şekil 5).

\section{Kontrol Ünitesi}

Kontrol ünitesinin üzerinde sondaya verilen basınç değerlerini ayrıntılı olarak gösteren manometreler vardır. GA-tipinde su-gaz basınç farklarını düzenleyen bir gösterge vardır. Buna karşın G-tipinde diferansiyel basınç göstergesi yoktur. Muhafaza hücresi ve merkezi hücre basınç değerleri farkından diferansiyel basınç değeri hesaplanır. Deney sırasında, verilen basınç altında zeminde oluşan hacim değişiklikleri volumetreden (hacimölçer) giden su miktarıyla belirlenir. Volumetrede $0.5 \mathrm{~cm}^{3}$ 'e kadar su gidişleri rahatlıkla gözlenebilir. Ek göstergelerle bu hassasiyet artırılabilir.

\section{Silindirik Sonda}

İstenen deney kotuna yerleştirilen ve radyal olarak genişleyen silindirik sondadır. Değişik çap ve uzunlukta olanları vardır (Şekil 6). İç içe geçirilmiş iki lastik kılıfın kaplanmasıyla oluşmuş metalik bir silindir ve iki hücreden meydana gelir. Deney sırasında muhafaza hücresi olarak adlandırılan dış kısımdaki koruyucu hücre kuru hava, $\mathrm{CO}_{2}$, nitrojen gazı gibi tüpten gelen gazlarla, iç kısımdaki merkezi hücre ise su ile dolar. Bu iki hücre birbirleriyle bağlantılı değildir. 
Hücreler, volumetre ile ayrı ayrı bağlantılıdır ve aynı basınç ile yüklenirler. Çizelge 2'de, açılacak sondaj çapıyla uyumlu sonda tipleri verilmiştir. Deneyin çıplak sondayla mı veya sonda üzerine geçirilecek yarık muhafazayla mı yapılacağına ilişkin değerlendirmelere göre sondaj kuyusu çap1 ve kullanılacak karotiyer belirlenmelidir. Kablolu (Wireline) takımın kullanıldığ sondajlarda, kuyu çapı 75 mm'den az olduğu için, 76 mm'lik karotiyer takımının açtığı kuyuya
75 mm'lik yarık muhafazalı BX sondası (sonda çap1 $58 \mathrm{~mm}$ ) girmemektedir. Bu duruma dikkat edilmesi gerekmektedir.

Çizelge 3'te sonda tipleri ve özellikleri verilmektedir. BX-tipi sonda yaygin olarak kullanılmaktadır ve referans sonda olarak bilinir. Sondaların ölçüm yapan kısmı yaklaşık olarak kendi uzunluğunun yarısıdır. AX sondasının ölçüm hücresi, B sondasıyla aynı hacime sahiptir ancak AX-probu daha uzundur.

Çizelge 2. Menard Presiyometre deneyinde kuyu çap1-prop-yarık muhafaza ve karotiyer uyumluluğu.

Table 2. Borehole diameter-probe-casing and casing compatibility in Menard pressuremeter test.

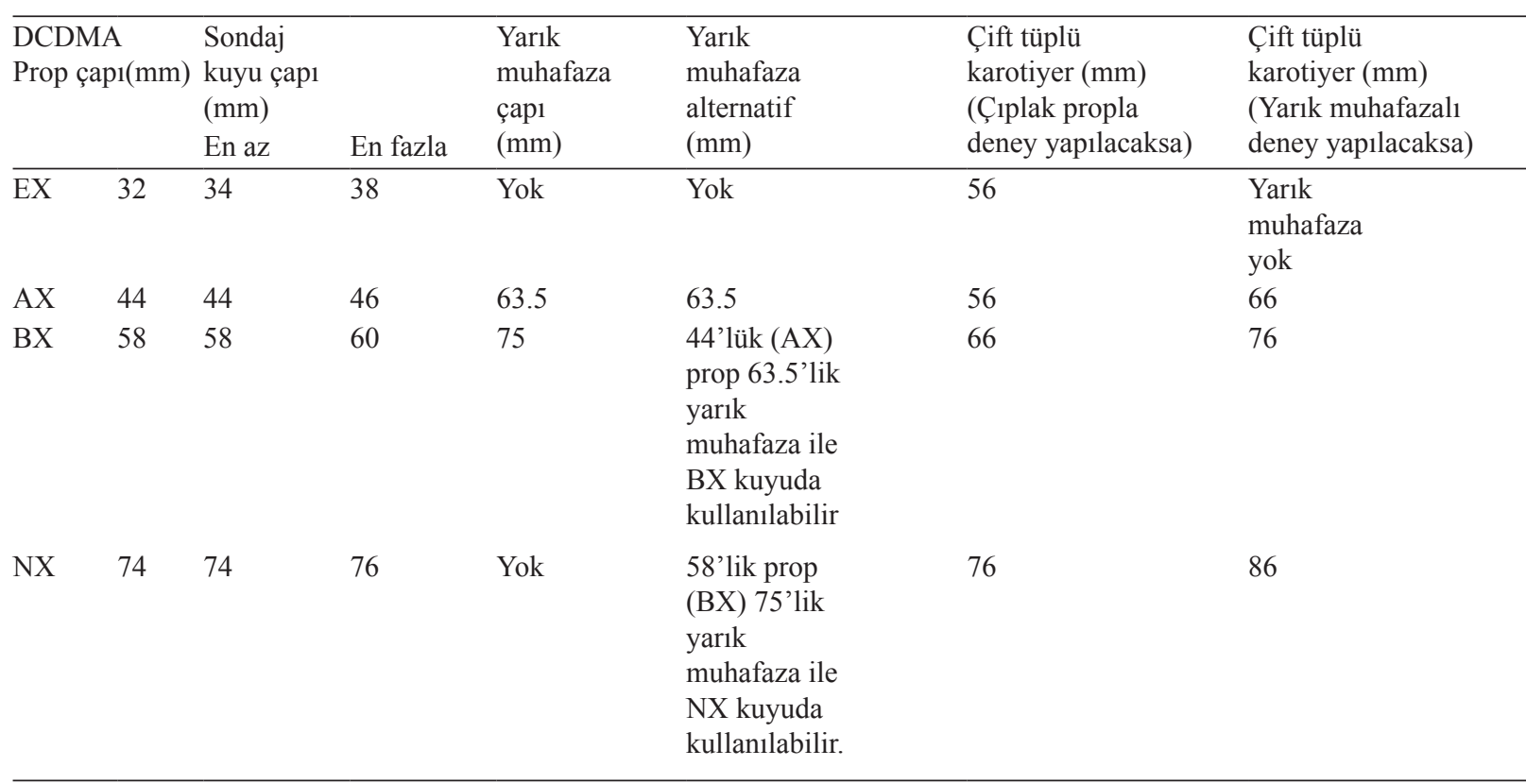

Çizelge 3. Tipik sonda ve kuyu boyutları.

Table 3. Typical probe and borehole dimensions.

\begin{tabular}{|c|c|c|c|c|}
\hline \multirow{2}{*}{$\begin{array}{c}\text { KODU } \\
\text { DCDMA }\end{array}$} & \multicolumn{2}{|c|}{$\begin{array}{c}\text { KUYU ÇAPI } \\
(\mathrm{mm})\end{array}$} & \multirow{2}{*}{$\begin{array}{l}\text { Prob Çapı } \\
(\mathrm{mm})\end{array}$} & \multirow{2}{*}{$\begin{array}{c}\begin{array}{c}\text { Ölçüm Hücres } \\
\text { Hacmi }\end{array} \\
V_{\mathbf{c}}\left(\mathrm{cm}^{3}\right) \\
\end{array}$} \\
\hline & Min & $\operatorname{Max}$ & & \\
\hline EX & 34 & 38 & 32 & 535 \\
\hline $\mathrm{AX}$ & 45 & 53 & 44 & 535 \\
\hline BX & 60 & 70 & 58 & 535 \\
\hline NX & 76 & 89 & 74 & 790 \\
\hline
\end{tabular}


Kayabaşı

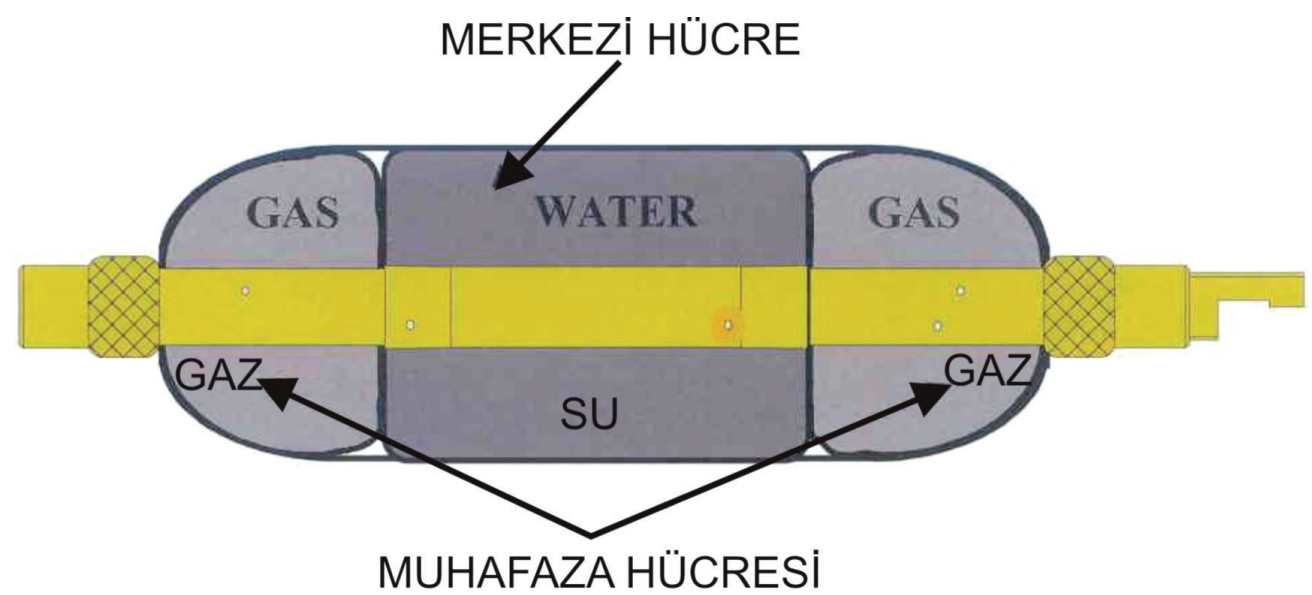

Şekil 6. G tipi presiyometre sondas1 ve kesiti (Apageo, 2006).

Figure 6. G type pressuremeter probe and its section (Apageo, 2006).

\section{İletim Hortumları}

Sonda ile kontrol ünitesi arasındaki bağlantıyı sağlayan iletim hortumları iç içe iki ayrı boru halinde üretilmiştir. İçteki boru saf suyu, dıştaki boru ise gazı iletir.
Tüp

Sistemin, dolaşım (sirkülasyon) basıncını karşılamak için sıkıştırılmış kuru hava, azot veya karbondioksit gazı kullanılabilir.
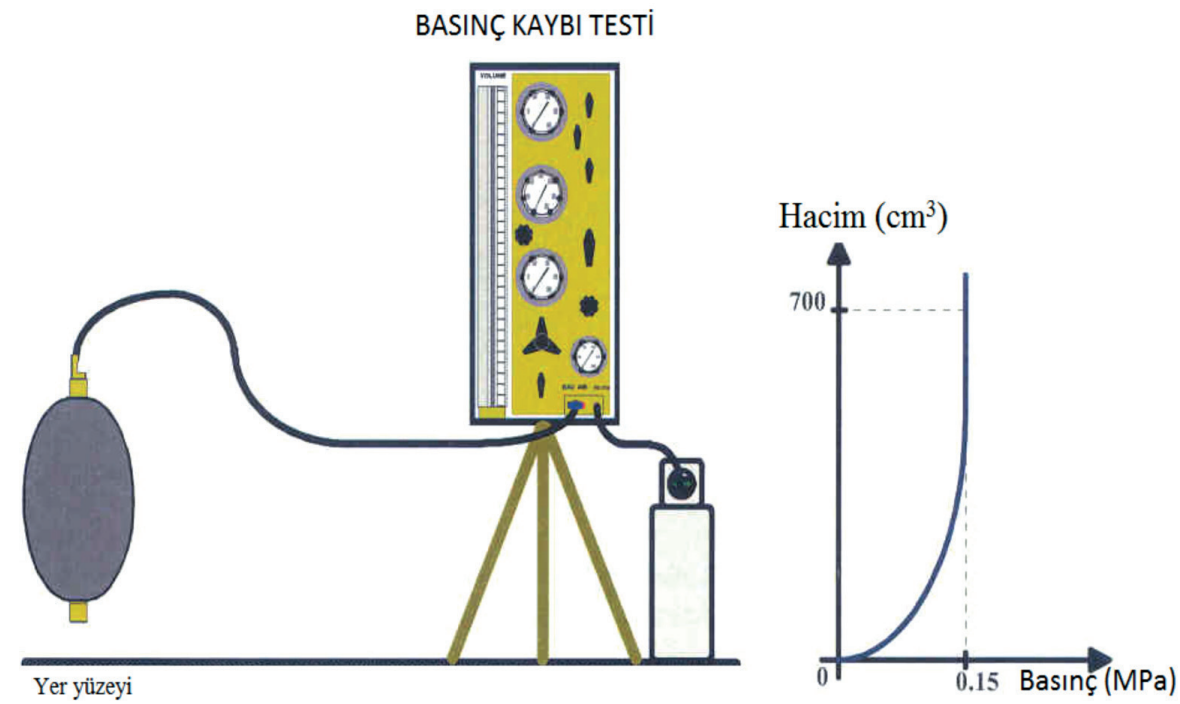

Şekil 7. Basınç kaybı testi (Apageo, 2006).

Figure 7. Pressure loss test (Apageo, 2006). 


\section{Menard Presiyometre Cihazının Deneye Hazırlanması}

Öncelikle sondanın merkezi hücresinde ve iletim hortumunun su bölümünde olabilecek hava su basılarak boşaltılır. Bu aşamada basınç kaybı deneyi, hacim kaybı deneyi, basınç farkının ayarlanması gibi cihaza ait kalibrasyonlar yapılmıştır. Yeni bir proje başlangıcında veya on deney sonrasi sonda lastiğinin esnemesi göz önüne alınarak, basınç kaybı deneyi ve hacim kaybı deneyi yeniden yapılmalıdır. Farklı presiyometre cihazına ait kalibrasyon değeri kullanılmamalıdır.

\section{Basınç Kaybı Deneyi}

Cihazın kendisini oluştan parçalarının ve sondanın lastik kısmının düşük bir direnci vardır. $\mathrm{Bu}$ direncin deneyin yapıldı̆̆ 1 zemine verilen basınç içine dâhil edilmemesi gerekir. Bunun için kuyu içine sonda sokulmadan, açık havada, toplam suyun $\left(700 \mathrm{~cm}^{3}\right)$ sondaya gidebileceği kadar basınç verilerek deney yapılır (Şekil 7). Bu uygulamanın adı basınç kaybı veya membran deneyidir. Bu basınç değerleri daha sonra deneyde oluşturulan basınç değerlerinden çıkartılır. Aras havzası Kuloğlu regülatör yerindeki deneyler için yapılan basınç kaybı deney grafiği ve verileri Şekil 8'de verilmiştir.

\section{Hacim Kaybı Deneyi}

Tüm su hattı boyunca oluşabilecek hacimsel bir genişleme deney sonuçlarını etkileyecektir. $\mathrm{Bu}$ nedenle, kuyu çapındaki kalibrasyon cihazı içerisine sonda sokularak hacim kayıpları belirlenir. Çelik kalibrasyon cihazı içinde, basınç karşılığında oluşan hacimsel genleşme verileri grafiklenir (Şekil 9). Sonda kuyu kotuna indirilir ve deney yapıldıktan sonra çelik muhafaza içinde alınan hacim değerleri, deney hacim değerlerinden çıkarılarak cihaza ait hacimsel

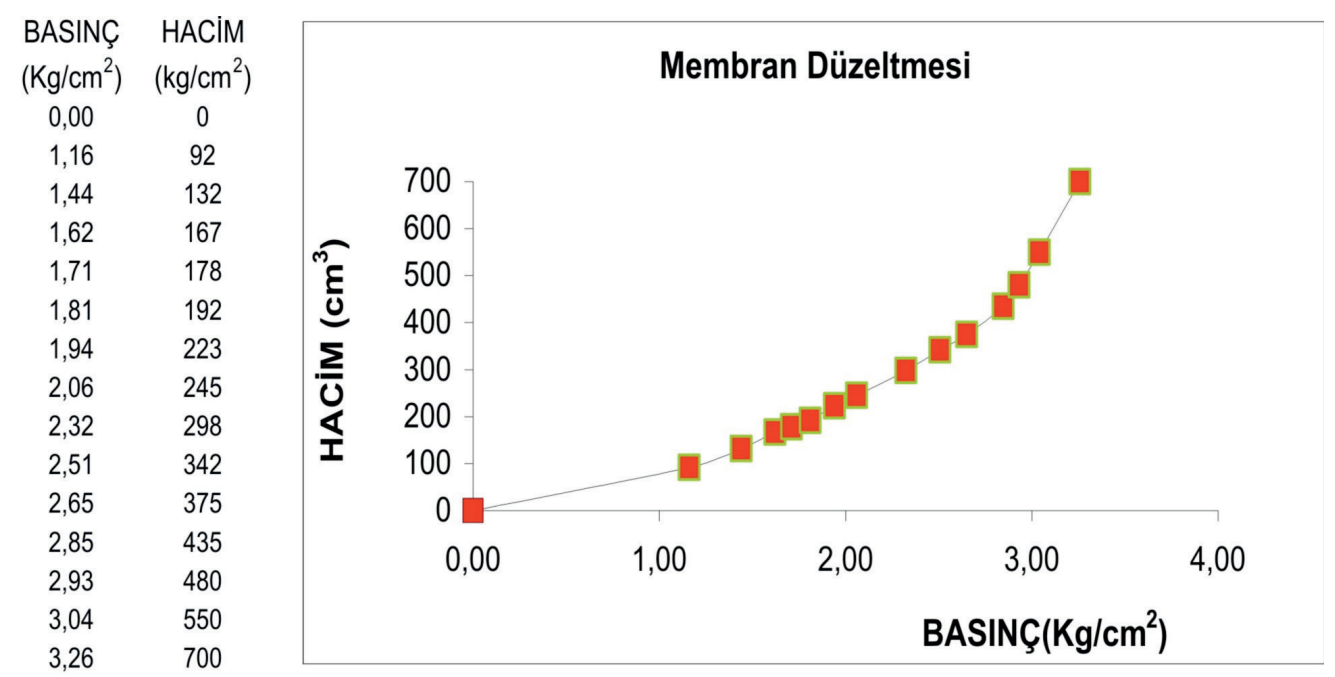

Şekil 8. Kuloğlu regülatör yerinde yapılan basınç düzeltmesi değerleri ve grafiği.

Figure 8. Pressure loss corrections and their graphs done at the Kuloğlu regulator site. 
Kayabaşı

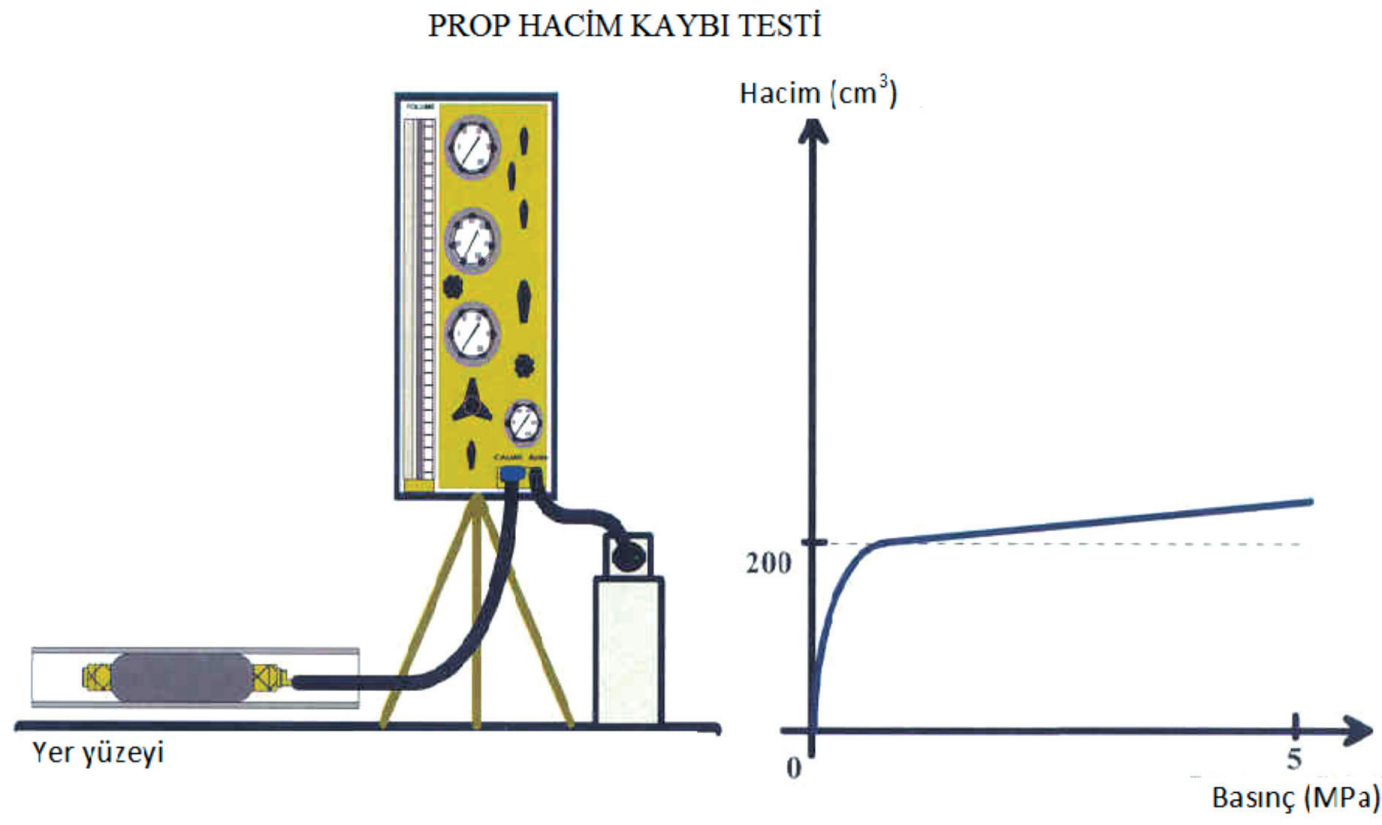

Şekil 9. Hacim kaybı testi (Apageo, 2006).

Figure 9. Volume loss test (Apageo, 2006).

genleşme giderilir. Aras havzası Kuloğlu regülatör yerindeki deneyler için yapılan hacim kaybı deneyi grafiği ve verileri Şekil 10'da verilmiştir.

\section{Hidrostatik Basınç Düzeltmesi}

Sonda derinlere indikçe, merkezi hücredeki suyun basinc1 artar. Yer yüzeyi ile deney seviyesi arasındaki basınç farkı diferansiyel düzeltme ile giderilir. Cihazın yüksekliği ile yer yüzeyi arasında oluşacak su basıncı da deney basınç verilerine eklenir (Şekil 11). Aras havzası Kuloğlu regülatör yerindeki Menard presiyometresi volümetresinin orta seviyesi ile yer yüzeyi arasındaki seviye farkı $60 \mathrm{~cm}$ 'dir. Bu seviye farkı nedeniyle oluşan 0.06 bar basınç deney basınç verilerine eklenmiştir.

\section{Diferansiyel Basınç Farkı}

Deney hortumu içerisinde iki bölüm vardır. Aynı şekilde deney sonda da iki bölümdür. $\mathrm{Bu}$ bölümler merkezi hücre ve gaz hücresidir. İki hücre arasında basınç farkı vardır. Bu farkın giderilmesi ve kuyu çeperlerine eşit basınç uygulanabilmesi için, diferansiyel basınç düzeltmesi yapılmalıdır. $\mathrm{Bu}$ düzeltme GA-tipi modellerde diferansiyel göstergesiyle yapılırken, G-tipi modellerde bu gösterge bulunmadığı için, merkezi hücre ve muhafaza hücresi arasındaki basınç farkı takip edilerek gerçekleştirilir.

Merkezi hücre (su) ve muhafaza hücreleri (gaz) arasındaki basınç farklılıkları ve etkileri giderilmelidir. Şekil 12'de görüldügü gibi durum 1, hatasız bir deney konumundaki merkezi hücrenin tamamıyla zemine yapışması durumunu göstermektedir. 


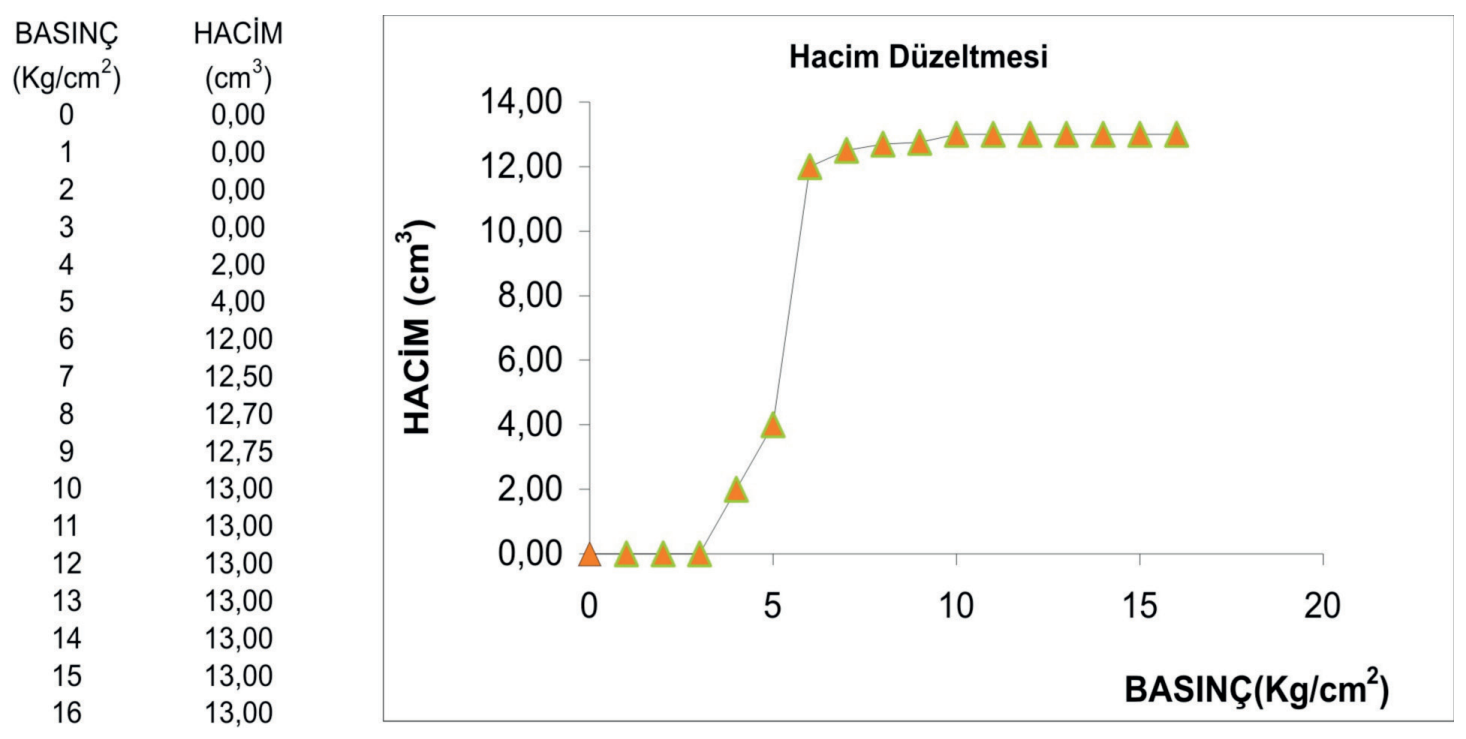

Şekil 10. Kuloğlu regülatör yerinde yapılan hacim düzeltmesi deneyi değerleri ve grafiği.

Figure 10. Volume loss test values and their graphs done at the Kuloğlu regulator site.

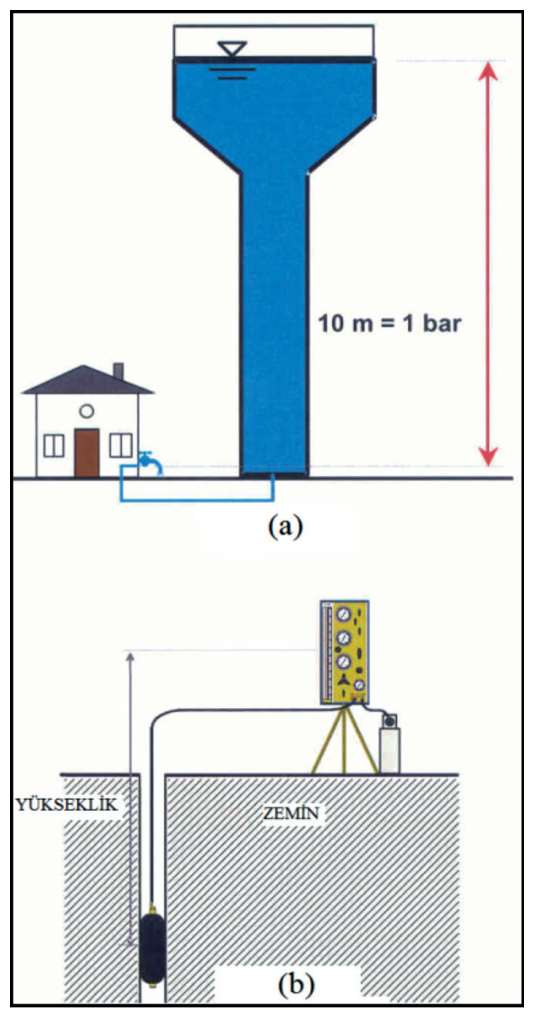

Şekil 11. Hidrostatik basınç farkı (a) Su seviyesi yükseldikçe hidrostatik basınç artışı, b)Hidrostatik basıncın belirlendiği kontrol ünitesinin altındaki su seviyesi yüksekliği (Apageo, 2006).

Figure 11. Hydrostatic pressure difference (a) Hydrostatic pressure increases with increasing water level, b) Water level below the control unit where hydroststic pressure is determined (Apageo, 2006). 
Kayabaşı
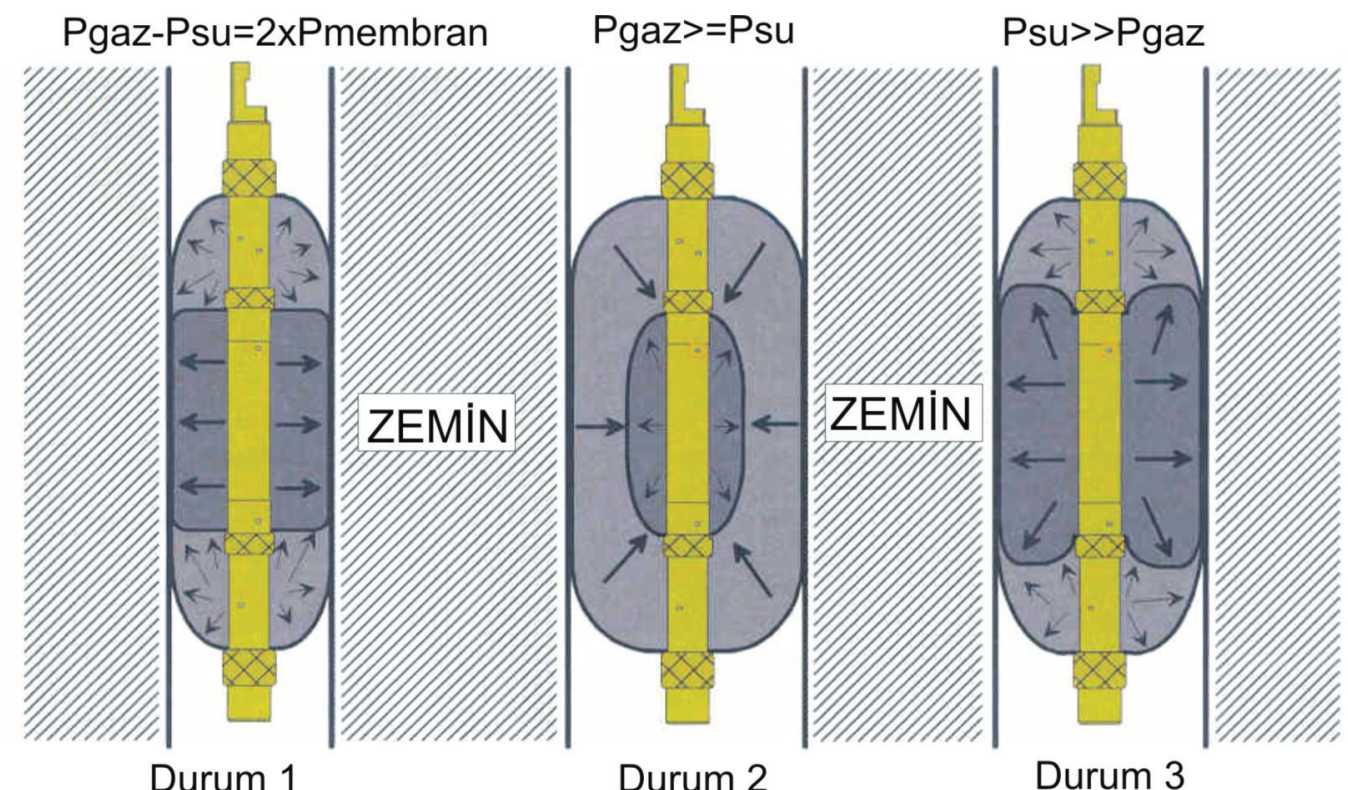

Durum 1

Durum 2

Durum 3

Şekil 12. Diferansiyel basınç farkı konumları (Apageo, 2006).

Figure 12. The conditions of differantial pressure differrence conditions(Apageo, 2006).

Durum 2'de ise muhafaza hücrelerindeki basınç fazlalı̆̆ merkezi hücrenin şişmemesini önlemektedir. Bu duruma bağlı olarak zeminle bağlantı kurulamamaktadır.

Durum 3'te ise merkezi hücresiye daha fazla basınç gitmesi ve muhafaza hücresine ise az basınç gitmesi konumunu gösterir. $\mathrm{Bu}$ durumda düşük basınçta fazla hacimsel genişlememeydana gelmekte ve hacim verileri gerçeği yansıtmamaktadır.

Durum 1'de görüleceği üzere manometreler yardımıyla muhafaza hücrelerindeki gaz basıncını, nispeten biraz daha az tutarak merkezi hücre ve muhafaza hücrelerinin sağlıklı şişmesi sağlanabilir. $\mathrm{Bu}$ diferansiyel basınç regülatörü düğmesi yardımıyla yapılabilmektedir.

Yüzeyde gaz hücresi basıncı ile merkez hücre basınc1 arasındaki fark 1 bar iken, 10 metre derinlikte her iki göstergedeki basınç değerleri aynı olur.
20 metre derinlikte, gaz hücresi 1 bar önde giderken 30. metrede bu fark 2 bara çıkmaktadır (Çizelge 4). Esas amaç sonda ve hortumlardaki hidrostatik su basıncını gidermektir.

\section{Menard Presiyometre Deneyinin Yapılışı}

Genel kural olarak presiyometre deneyi sondaj işleminden hemen sonra yapılmalıdır. Yapılacak araştırmanın niteliğine bakılmaksızın derinliğin bir fonksiyonu olarak direnç parametrelerinin değişimlerinin daha ayrıntılı olarak kayıt edilebilmesi için deneyler sistematik olarak her metrede bir kez tekrarlanmalidir. Kural olarak incelenen üst yapının genişliğinin yaklaşık iki katı derinliğe kadar, her metrede deney yapılmalıdır (Baquelin vd., 1978).

Kalibrasyonu daha önce yapılmış olan sonda, kuyu içine, deneyin yapılacağı derinliğe 
Çizelge 4. Prob derinliğinin fonksionu olarak diferansiyel göstergesi basınç farkı $\left(\mathrm{P}_{\text {diff }}\right)$.

Table 4. Pressure lag $\left(P_{\text {diff }}\right)$ as a function of probe depth.

\begin{tabular}{cc}
$\begin{array}{c}\text { Prob Derinliği } \\
(\mathbf{m})\end{array}$ & $\begin{array}{c}\text { Muhafaza Hücresi Göstergesi ve } \\
\text { Merkezi Hücre Göstergesi Farkı (bar) }\end{array}$ \\
\hline $0^{*}$ & $-1,0$ \\
1 & -0.9 \\
2 & -0.8 \\
3 & -0.7 \\
4 & -0.6 \\
5 & -0.5 \\
6 & -0.4 \\
7 & -0.3 \\
8 & -0.2 \\
9 & -0.1 \\
10 & Eşit Basinç \\
11 & 0.1 \\
12 & 0.2 \\
20 & *Kalibrasyon testi için (For calibration test) \\
\hline
\end{tabular}

indirilir ve basınçlı hava $\left(\mathrm{CO}_{2}\right.$, vb.) ile şişirilir. Sondanın şişmesi ve buna bağlı olarak boşluğun genişlemesini sağlamak için gaz tüpünden regülatör (dedantör) yardımı ile ölçme hücresine eşit aralıklarla (1-2-3 bar) arttırılan basınçlar uygulanır. Arttırılan her basınç seviyesinde, sabit bir zaman aralığına kadar (genellikle 1 dakika) beklenilir. Belirlenen bu zaman aralığında her basınç $\operatorname{artış1~}\left(\mathrm{p}_{\mathrm{m}}\right)$ için ölçme hücresindeki hacim değişimleri $\left(\mathrm{V}_{\mathrm{m}}\right)$ kaydedilir. Boşluk hacminde oluşan artış, kuyunun yalnız çapsal olarak genişlemesi şeklinde gelişir. Bir deney zonuna en az 10 kademelik basınç uygulanır. Böylece bir deney yaklaşık olarak 10-15 dakika sürer.

Kayıtların alımından sonra hacim ve basıncın artan değerleri üzerinde gerekli düzeltmeler yapılır. Şekil 13'te Kuloğlu regülatör yerinde açılan SK-1 nolu kuyuda 7.50 ile 9.00 $\mathrm{m}$ arasinda yapılan presiyometre deney verileri görülmektedir. 2 nolu sütunda deneyde uygulanan basınç artışları verilmiştir. Üç nolu sütunda ise, basınç artışlarının karşılığında oluşan hacimsel genişleme değerleri verilmiştir. 2 ve 3 nolu sütun verileri, düzeltme yapılmamış ham verilerdir. 4 nolu sütundaki veriler eklenen hidrostatik basınç değerleridir. SK-1 kuyusunda deney yapılırken sondaj kuyusu seviyesiyle presiyometre cihazı volumetre tüpünün ortasına kadar olan yükseklik $60 \mathrm{~cm}$ ölçülmüştür. Bu değer deney çizelgesinde manometre yüksekliği seviyesi $0.6 \mathrm{~m}$ olarak kayıt edilmiştir. $60 \mathrm{~cm}$ yükseklikteki bir su sütunu 0.06 $\mathrm{kg} / \mathrm{cm}^{2}$ basınç yapacağ 1 için, deneyde uygulanan basınç değerlerine $0.06 \mathrm{kgf} / \mathrm{cm}^{2}$ ek basınçlar ilave edilerek 4-nolu sütun oluşturulur. 5-nolu sütun değerleri hacim kalibrasyonu değerleridir. Deneyde uygulanan basınç değerlerinin karşılığ 1 , yüzeyde kalibrasyon borusu içerisine sonda sokarak yapılan deneye ait hacim değerleridir. 
Kayabaşı

$\mathrm{Bu}$ hacim değerleri deneyde kayıt edilen hacim verilerinden çıkartılarak 6 nolu sütun oluşturulur. 7 nolu sütundaki basınç değerleri sondanın yer yüzeyinde açık havada $700 \mathrm{~cm}^{3}$ 'e kadar şişirilmesi için gereken basınç değerleridir. 7 nolu sütundaki basınç değerleri, deneyde kullanılan ve hidrostatik basıncın da ilave edildiği basınç değerlerinin verildiği 4-nolu sütundaki verilerden çıkarılarak 8-nolu sütundaki düzeltilmiş basınç değerleri belirlenir.

6-nolu sütundaki düzeltilmiş hacim değerleri ve 8-nolu sütundaki düzeltilmiş basınç değerlerinden presiyometre grafiği çizilir. Her deney için çizilen bu grafiklerden, Menard deformasyon modülü $\left(\mathrm{E}_{\mathrm{M}}\right)$ ve zeminin yenilmesi halinde net limit basınç $\left(\mathrm{P}_{1}^{*}\right)$ değerleri hesaplanır.

\section{Menard Deformasyon Modülü $\left(\mathrm{E}_{\mathrm{M}}\right)$ 'nün Hesaplanması}

Baqulelin vd. (1978)'de elastik bir ortamda, silindirik bir boşluğun radyal genişlemesi sırasında basınç $(\Delta \mathrm{P})$ artması ile çapta meydana gelen hacim $(\Delta V)$ değişmesi ilkesinden hareketle, Menard Deformasyon Modülü'nün (E) aşağıdaki eşitlikten hesaplanacağını belirtmiştir.

$$
\begin{aligned}
& \mathrm{E}=\mathrm{k} \cdot \Delta \mathrm{P} / \Delta \mathrm{V} \\
& \mathrm{k}=(1+v) 2\left(\mathrm{~V}_{\mathrm{c}}+\mathrm{V}_{\mathrm{m}}\right)
\end{aligned}
$$

Poisson oranının 0.33 alınması durumunda

$$
\mathrm{E}=2.66\left(\mathrm{~V}_{\mathrm{c}}+\mathrm{V}_{\mathrm{m}}\right) \Delta \mathrm{P} / \Delta \mathrm{V}
$$

$\Delta \mathrm{P}$ : Kalibrasyonları yapılarak çizilmiş presiyometre deney eğrisinde, doğrusal (lineer) kısımdaki basınç farkı
$\Delta \mathrm{V}:$ Kalibrasyonları yapılarak çizilmiş presiyometre deney eğrisinde, doğrusal (lineer) kısımdaki hacim farkı

$\mathrm{V}_{\mathrm{c}}$ : Probun boş hacmi

$\mathrm{V}_{\mathrm{m}}$ : Eğrinin doğrusal kısmında proba verilen ortalama hacim

v: Poisson Oran1

Şekil 13 incelenecek olursa, hacim-basınç eğrisinin kuyu çeperine yapışıncaya kadar dikey olarak yükseldiği, kuyu çeperine tam yapışmanın ve tam hacimsel genişlemenin başlamasının, yani $\mathrm{P}_{\mathrm{o}}$ noktasının $1.76 \mathrm{kgf} / \mathrm{cm}^{2}$ olduğu ve bu değere karş1lık gelen $v_{0}$ değerinin $105 \mathrm{~cm}^{3}$ olduğu görülür. $\mathrm{Bu}$ noktadan sonra grafik eğrisinde doğrusal bir kısım başlar. Bu doğrusal kısım; zeminin elastik özelliklerini belirler. Doğrusallığın bittiği nokta, akma noktası $\left(\mathrm{P}_{\mathrm{f}}\right)$ olarak tanımlanır. Akma noktasından sonraki aşama, zeminin plastik davranış sergilediği kısımdır.

$$
\begin{aligned}
& \Delta \mathrm{P}=\mathrm{P}_{\mathrm{f}}-\mathrm{P}_{\mathrm{o}}=8.34-1.76=6.58 \mathrm{kgf} / \mathrm{cm}^{2} \\
& \Delta \mathrm{V}=\mathrm{V}_{\mathrm{f}}-\mathrm{V}_{\mathrm{o}}=186-105=81 \mathrm{~cm}^{3} \\
& \mathrm{~V}_{\mathrm{m}}=81 / 2+105=145.5 \mathrm{~cm}^{3} \\
& \mathrm{E}_{\mathrm{M}}=2.66 *(535+145.5) *(6.58 / 81)=147.05
\end{aligned}
$$
$\mathrm{kgf} / \mathrm{cm}^{2}$

\section{Limit Basıncın ( $\mathbf{P}_{\mathbf{P}}$ ) Bulunması}

Limit basıç̧; teorik olarak zeminde açılmış olan silindirik boşluğun ilksel hacminin iki katına ulaştı̆̆ 1 hacmine $\left(2 \mathrm{v}_{\mathrm{O}}+\mathrm{V}_{\mathrm{c}}\right)$ karşı1ık gelen basınç değeridir. Şekil-14'te görülebileceği gibi limit basıncın tanımlandığı koşul; deneyin yapıldığ kuyu çapının iki katına ulaştırılabilmesi için 


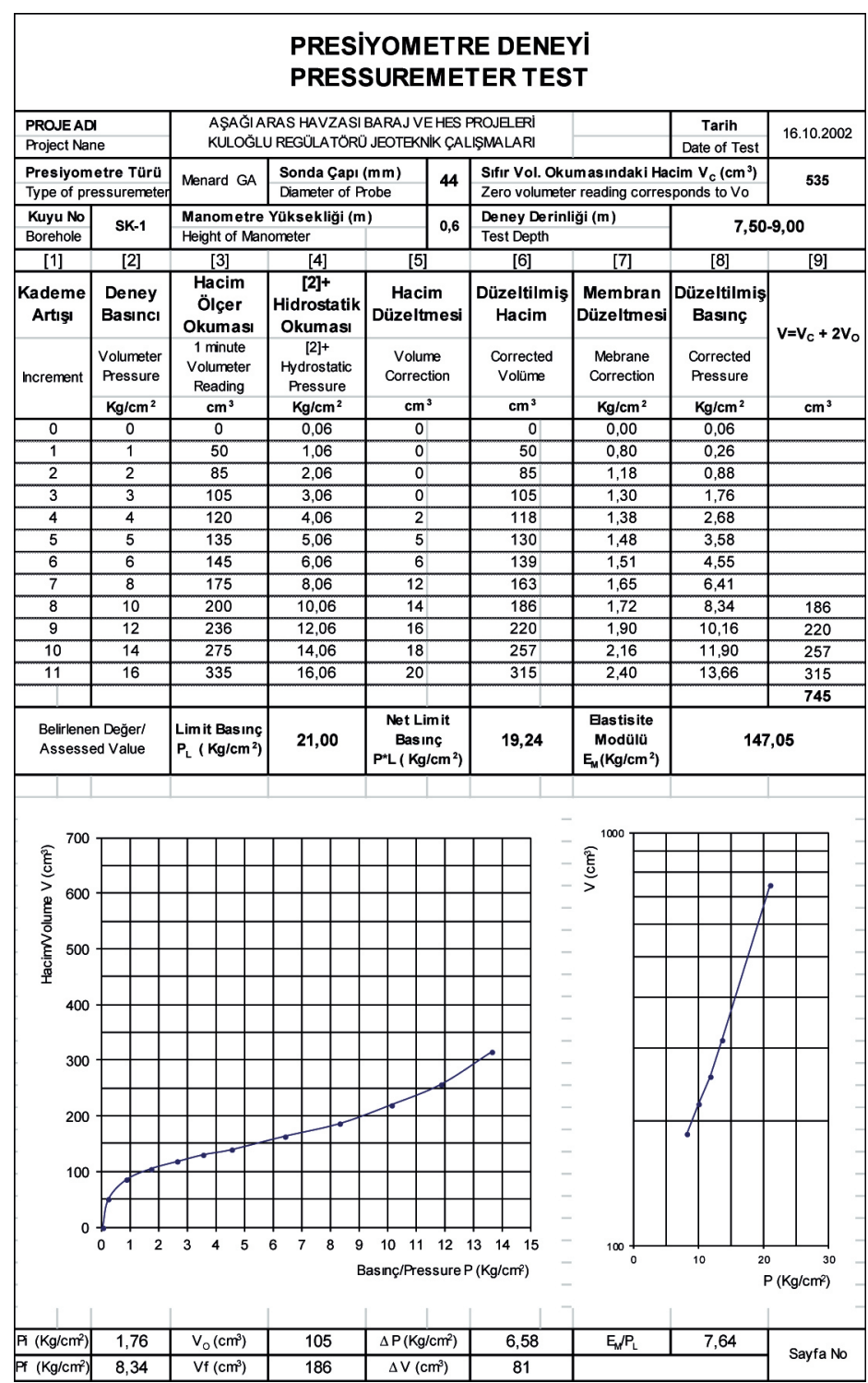

Şekil 13. Kuloğlu regülatör yerinde SK-1 nolu kuyuda 7.50-9.00 m arasında yapılan presiyometre deneyi verileri.

Figure 13. The pressuremeter test results performed at 7.50-9.00 m depth of SK-1 for the Kuloğlu regulator site.

cihazdan sondaya gönderilen su hacmine karşı1lık gelen basınç değeridir.

$$
\mathrm{Vt}=2 \mathrm{v}_{\mathrm{o}}+\mathrm{V}_{\mathrm{c}}
$$

$\mathrm{V}_{\mathrm{c}}$ : Presiyometre sondasinın hacmi

$\mathrm{v}_{\mathrm{o}}$ : Deneyin başlamasından sonra sondanın şişerek kuyu çapına yaslandığ
Vt: Deneyin yapıldı̆̆ katına çıktığı hacim

Vt-hacmini oluşturan basınç değeri limit basınç $\left(\mathrm{P}_{1}\right)$ değeridir. Deney sırasında elde edilen hacimsel artış 4 nolu eşitliğin değerinden daha az ise; deney sırasında elastik safha-plastik safha 

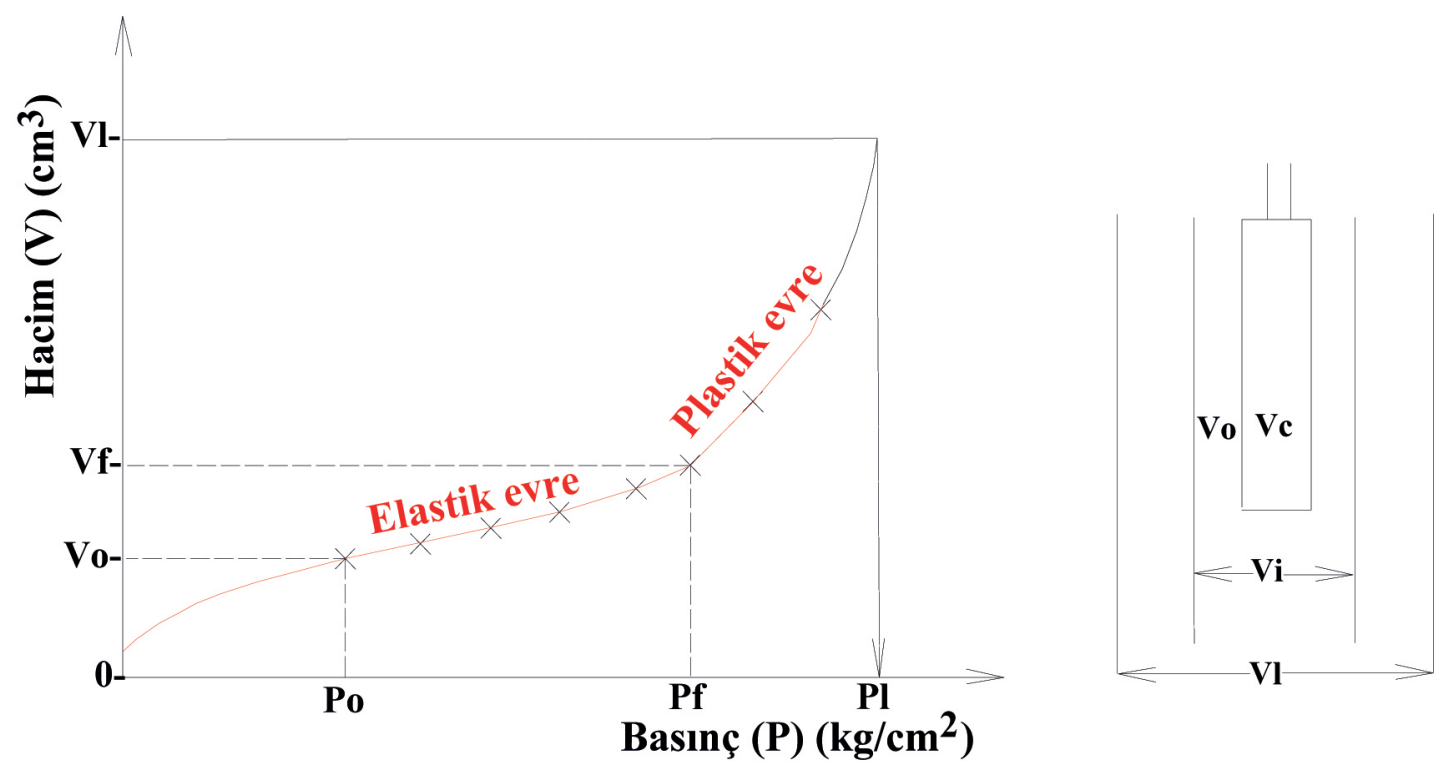

Şekil 14. Presiyometre deney eğrisinin şekli ve bölümleri.

Figure 14. The shape of the pressuremeter test curve and its sections.

sınırını aşması şartıyla limit basınç değeri tahmin edilebilir. Limit basınç $\left(\mathrm{P}_{1}\right)$, kuyu çeperinde artan üniform basıncın etkisi altında kalan bir zeminin yenilmesinin sınır durumuna karşılık gelir ve zeminin teorik olarak nihai taşıma gücünü temsil eder. Erdoğan (1980) sert zeminlerde deformasyonların az olması nedeniyle yüksek basınç altında dahi silindirik boşluğun ilksel hacminin iki katına ulaşılamama durumunda, grafik eğrisinin $700 \mathrm{~cm}^{3}$ 'e karşılık gelen basınç değerini limit basınç $\left(\mathrm{P}_{1}\right)$ olarak tanımlar.

Bir eğrinin uzatılması için kullanılan en basit ve yaygın yöntem, eğriyi $\mathrm{P}-\mathrm{V}$ grafiği üzerinde devam ettirmektir. Eğrinin uzatılma işlemi pistole veya diğer çizim araçları ile yapılabilir (Şekil 15). $\mathrm{P}_{\max }$ ve $\mathrm{V}_{\max }$ noktas1 (yani eğrinin son noktas1) eğrinin eğimi (veya yönelimi) yönünde $\left(2 \mathrm{v}_{\mathrm{o}}+\mathrm{V}_{\mathrm{c}}\right)$ değerine kadar (hacim ekseninde) uzat1lir. $2 \mathrm{v}_{0}+\mathrm{V}_{0}$ noktası, deney boşluğunun boyut olarak iki kat olduğu noktadır. $2 \mathrm{v}_{\mathrm{o}}+\mathrm{V}_{\mathrm{c}}$ hacmine eş gelen basınç değeri limit basıncı $\left(\mathrm{P}_{1}\right)$ oluşturur. $\mathrm{Bu}$ işlem el ile çizim yapıldığ 1 için, manuel limit basınç yöntemi olarak isimlendirilir. Şekil 15 'te görüldüğü gibi SK-1 kuyusunda 7.00 $9.50 \mathrm{~m}$ arasinda yapilan presiyometre deney grafiği eğrisi $2 \mathrm{v}_{\mathrm{o}}+\mathrm{V}_{\mathrm{c}}=745 \mathrm{~cm}^{3}$ değerine kadar uzatılarak, bu hacmi oluşturan basınç değeri yani limit basınç $\left(\mathrm{P}_{1}\right)=20 \mathrm{~kg} / \mathrm{cm}^{2}$ olarak belirlenmiştir. Net limit basıncın bulunabilmesi için, presiyometre probunun zeminde hacimsel değişim oluşturmaya başladığı basınç değerini limit basınç değerinden çıkarmamız gereklidir.

Net limit basınç ise $\mathrm{P}_{1}^{*}=\mathrm{P}_{1}-\mathrm{P}_{\mathrm{o}}=20-1.76=$ $18.24 \mathrm{kgf} / \mathrm{cm}^{2}$ ' dir. 
İnterpolasyon Yöntemi ile limit basıncın belirlenmesi

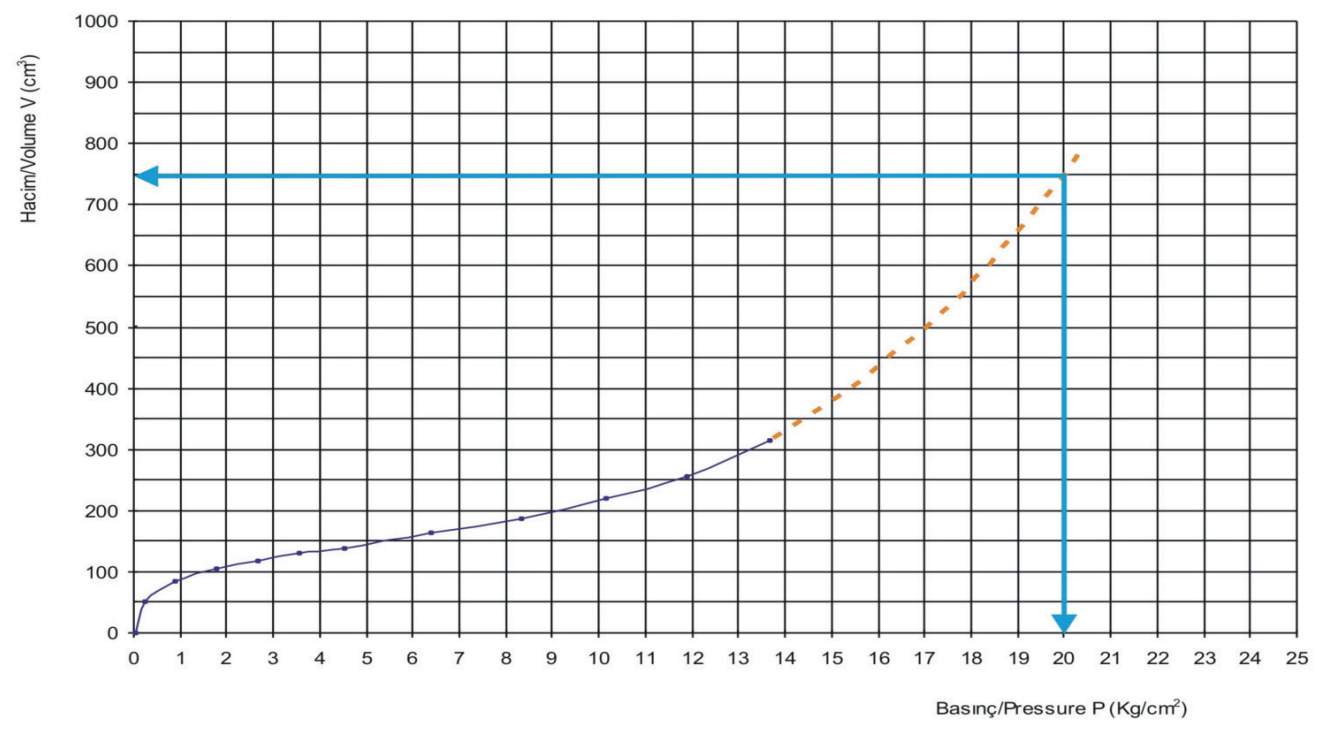

Şekil 15 İnterpolasyon yöntemi ile limit basınç $\mathrm{P}_{1}$ değerinin belirlenmesi.

Figure 15. Determination of the limit pressure $\left(P_{\nu}\right)$ by utilizing the interpolation method.

El ile presiyometre grafik eğrisinin uzatılması işlemi kişiden kişiye değişsebilir ve bu nedenle de subjektiftir. Bu nedenle literatürde daha objektif yöntemler önerilmiştir. Bunlar Log-Log Yöntemi (Jézéquel vd., 1974), Ters Çevirme Yöntemi (Van Wambrake ve D'henrı Court, 1971) ve Göreceli Hacim Yöntemi (Centre d'Etudes Menard, 1971) şeklinde sayılabilir.

Log-Log yöntemine göre SK-1 kuyusunda 7.50-9.00 $\mathrm{m}$ derinlikte yapılan presiyometre deneyinin net limit basinc1 $\left(\mathrm{P}_{1}^{*}\right)$ değerini hesaplarsak; Şekil 13'te 9 nolu sütunda düzeltilmiş hacim değerlerinin son 4 değeri verilmiştir. $\mathrm{Bu}$ son dört değerin her iki eksenin logaritmik olduğu P-V grafiğinde çizilmesi sonucu grafik eğrisi düz bir çizgi olur. Bu çizginin $2 \mathrm{v}_{\mathrm{o}}+\mathrm{V}_{\mathrm{c}}=2 *(105)+535=745 \mathrm{~cm}^{3}$ 'e uzatılmasiyla bulunan basınç değeri limit basınç $\mathrm{P}_{1}=21 \mathrm{~cm}^{3}$ olacaktır. Net limit basıncının bulunabilmesi için, presiyometre probunun zeminde hacimsel değişim oluşturmaya başladığ 1 basınç değerini limit basınç değerinden çıkarmamız gereklidir.

Net limit basınç ise $\mathrm{P}_{1}^{*}=\mathrm{P}_{1}-\mathrm{P}_{\mathrm{o}}=21-1.76=$ $19.24 \mathrm{kgf} / \mathrm{cm}^{2}$ ' dir.

Aşağ1Aras havzası kuloğlu regülatör yerinde açılan SK-1 ve SK-2 kuyularında da çeşitli kademelerde yapilan presiyometre deneyleri sonucunda belirlenen Menard Deformasyon Modülü $\left(\mathrm{E}_{\mathrm{M}}\right)$ ve Limit Basınç $\left(\mathrm{P}_{1}\right)$ değerleri şekil16'da verilmiştir. Çizelge 5'te SK-1 ve SK-2 kuyularında deney sonuçlarının istatistiksel değerlendirilmesi verilmiştir. Kuloğlu regülatör yerinde belirlenen ortalama Menard deformasyon modülü ve ortalama limit basınç değerleri, çizelge 6'da Baguelin vd. (1978)'e göre verilen verilerle uyumluluk göstermektedir. 
Kayabaşı

Çizelge 5. Kuloğlu regulatör yerinde yapılan Menard presiyometre deneylerinin istatistiksel değerlendirmesi.

Table 5. Statistical evaluation of the Menard pressuremeter test performed at the Kuloğlu regulator site.

\begin{tabular}{|c|c|c|c|c|c|c|c|}
\hline Parametre & $\begin{array}{c}\text { Parametre } \\
\text { say1s1 }\end{array}$ & Aralık & En düşük & En yüksek & Ortalama & Std. sapma & Varyans \\
\hline Menard Modülü, $\mathrm{E}_{\mathrm{M}}\left(\mathrm{kgf} / \mathrm{cm}^{2}\right)$ & 20 & 376.59 & 35.58 & 412.17 & 177.59 & 98.24 & 9651.15 \\
\hline $\begin{array}{l}\text { Net Limit Basınç } \\
\mathrm{P}_{1}^{*}\left(\mathrm{kgf} / \mathrm{cm}^{2}\right)\end{array}$ & 20 & 39.04 & 6.48 & 45.52 & 28.74 & 11.31 & 128.06 \\
\hline
\end{tabular}

\section{KULOĞLU REGÜLATÖR YERİNDE} PRESIYYMETRE DENEYI

\section{SONUÇLARIYLA TEMEL BIRIMININ}

TAŞIMA GÜCÜNÜN BELIRLENMESİ

Kuloğlu regülatör yeri proje özellikleri şu şekildedir:
Proje yükü $\left(\mathrm{q}^{*}\right)=3.2 \mathrm{kgf} / \mathrm{cm}^{2}$

Temelin uzun kenarı uzunluğu $(\mathrm{L})=2400 \mathrm{~cm}$

Temelin kısa kenarı uzunluğu $(B)=2400 \mathrm{~cm}$

Temel kazı derinliği $\left(D_{\mathrm{f}}\right)=300 \mathrm{~cm}$

Alüvyon birim hacim ağırlığı $\left(\gamma_{\mathrm{n}}\right)=1.83 \mathrm{gr} / \mathrm{cm}^{3}$

Güvenlik katsayısı $(\mathrm{F})=3$

Çizelge 6. Tipik zeminlerde Menard modulü ile limit basınç arasındaki ilişki.

Table 6 The relationship between Menard modulus and limit pressure for typical soils.
Zemin Cinsi
Menard Modülü $\left(E_{M}\right)\left(k N / m^{2}\right)$
Limit Basınç ( $\left.P_{1}\right)\left(k N / m^{2}\right)$

\begin{tabular}{lcc}
\hline Balçık & $200-500$ & $20-150$ \\
Yumuşak Kil & $500-3000$ & $50-300$ \\
Plastik Kil & $3000-8000$ & $300-800$ \\
Sert Kil & $8000-40000$ & $600-2000$ \\
Marn & $5000-60000$ & $600-4000$ \\
Gevşek Siltli Kum & $500-2000$ & $100-500$ \\
Silt & $2000-10000$ & $200-1500$ \\
Kum ve Çakıl & $8000-40000$ & $1200-5000$ \\
Tortul Kum & $7500-40000$ & $1000-5000$ \\
Kireçtaşı & $80000-20000000$ & $3000-10000$ \\
Yeni Toprak Dolgu & $500-5000$ & $50-300$ \\
Eski Toprak Dolgu & $4000-15000$ & $400-1000$ \\
\hline
\end{tabular}



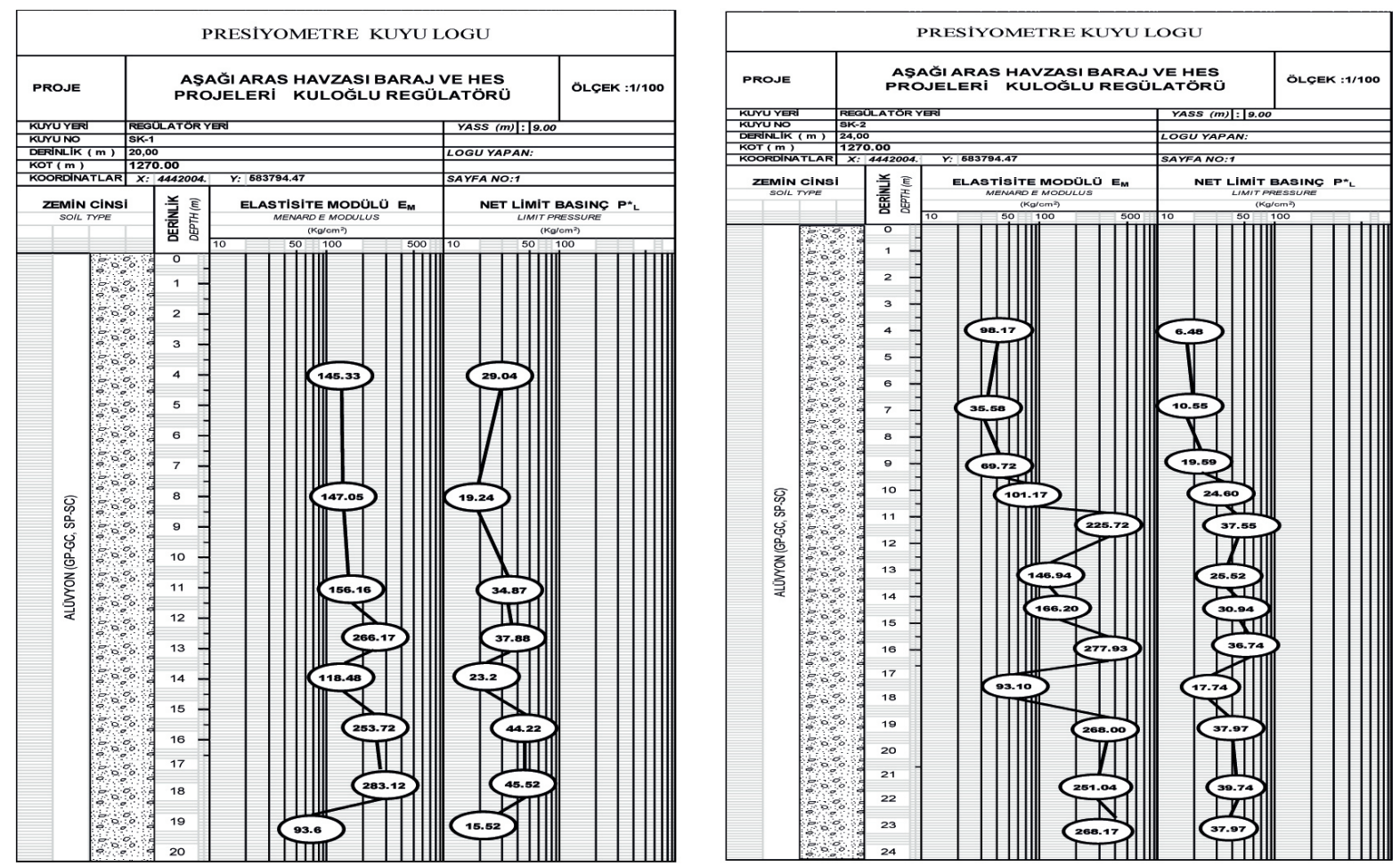

Şekil 16. SK-1 ve SK-2 nolu kuyuların presiyometre deney logları.

Figure 16 The pressuremeter borehole logs of SK-1 and SK-2.

Baquelin vd. (1978) taşıma gücü için aşağıdaki eşitlikleri önermiştir:

$$
\begin{aligned}
& \mathrm{q}_{\mathrm{u}}=\mathrm{q}_{\mathrm{o}}+\mathrm{k} *\left(\mathrm{P}_{\mathrm{lc}} *\right) \\
& \mathrm{q}_{\mathrm{a}}=\mathrm{q}_{\mathrm{o}}+\left(\mathrm{kP}_{\mathrm{lc}} * / \mathrm{F}\right)
\end{aligned}
$$

\section{$\mathrm{q}_{\mathrm{u}}$ : Nihai taşıma gücü}

$\mathrm{q}_{\mathrm{o}}$ : Temel taban seviyesinde zemine uygulanan düşey gerilme değeri (Temel taban basinc1)

$\mathrm{k}$ : Temel şekli, derinliği ve zeminin cinsine bağlı olarak (kil, silt, kum, çakıl ve zayıf kaya) elde edilen bir katsayı (k katsayısı Şekil 17'deki grafiklerden veya Çizelge 7'deki eşitlikler yardımıyla belirlenebilir)

$$
\begin{aligned}
& \mathrm{P}_{\mathrm{lc}}^{*} \text { : Eşdeğer net limit basınç } \\
& \mathrm{q}_{\mathrm{a}} \text { : İzin verilebilir taşıma gücü }
\end{aligned}
$$

Eşdeğer limit basıncı $\left(\mathrm{P}_{\mathrm{lc}}^{*}\right)$, presiyometre deneyiyle elde edilen net limit basınçlarının, Eşitlik 7'ye göre geometrik ortalaması alınarak elde edilir. $\mathrm{P}_{\mathrm{lc}}{ }^{*}$ değerinin hesaplanması, öncelikle yapının oturacağ B/2 aralıklarına bölünmesiyle olur. Burada B, temelin kısa kenar uzunluğudur (Şekil 18). 
Kayabaşı

Çizelge 7. Taşıma gücü katsayısı (k) değerleri.

Table 7. The value of bearing capacity factor $(k)$.

\begin{tabular}{lc}
\hline Zemin cinsi & $\mathbf{k}$ \\
\hline Kohezyonlu & $1+0,2 \mathrm{~B} / \mathrm{L}$ \\
Daneli - gevşek & $1.1+0.2 \mathrm{~B} / \mathrm{L}$ \\
Daneli - sık1 & $1.2+0.4 \mathrm{~B} / \mathrm{L}$ \\
\hline B = temel genişliği, L = temel uzunluğu & \\
\hline
\end{tabular}

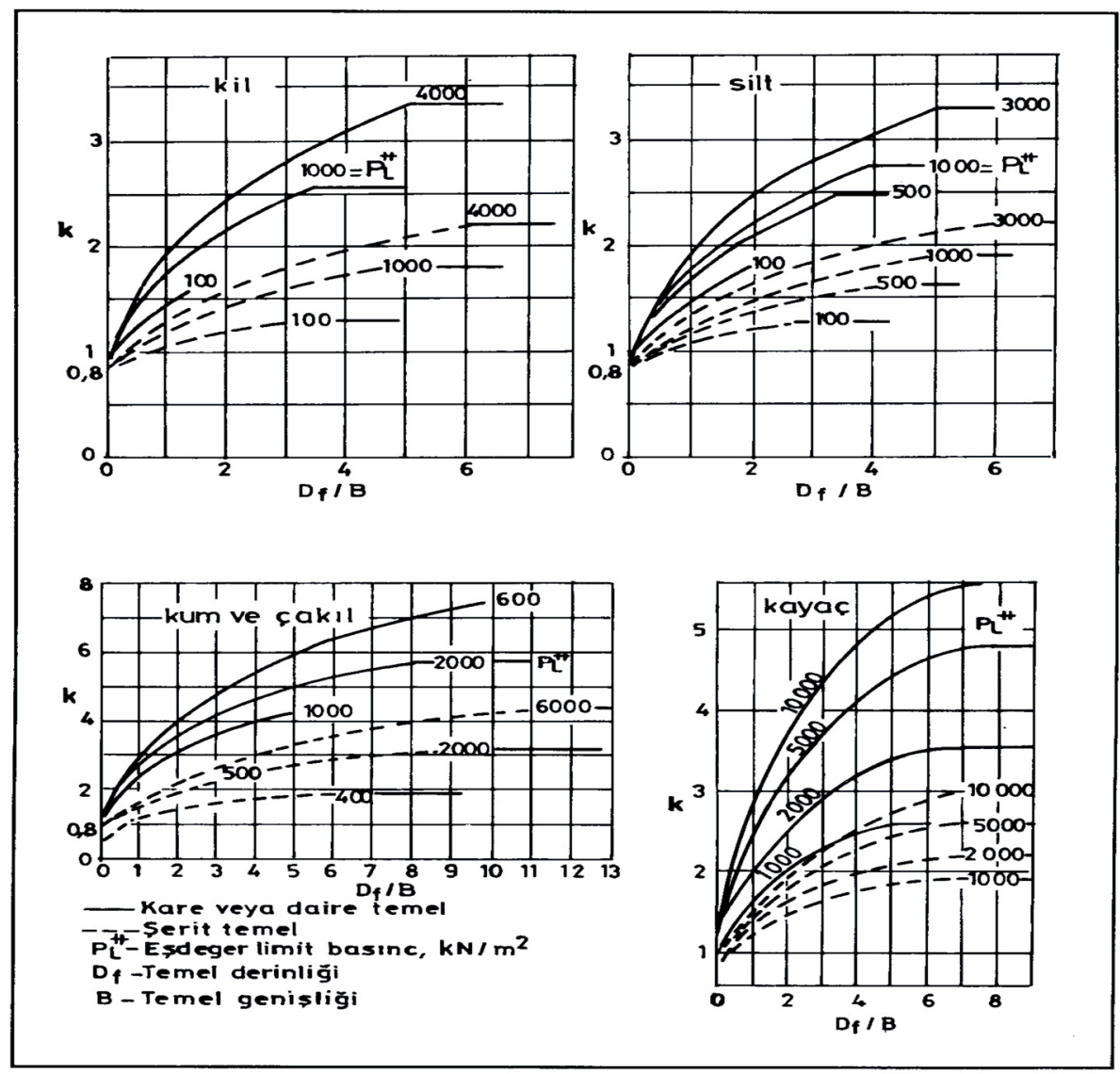

Şekil 17. Taşıma gücü faktörü (k) tespiti için hazırlanmış grafikler (Baquelin vd., 1978).

Figure 17. The graphes for the determination of bearing capacity factor (k)(Baquelin et al., 1978). 


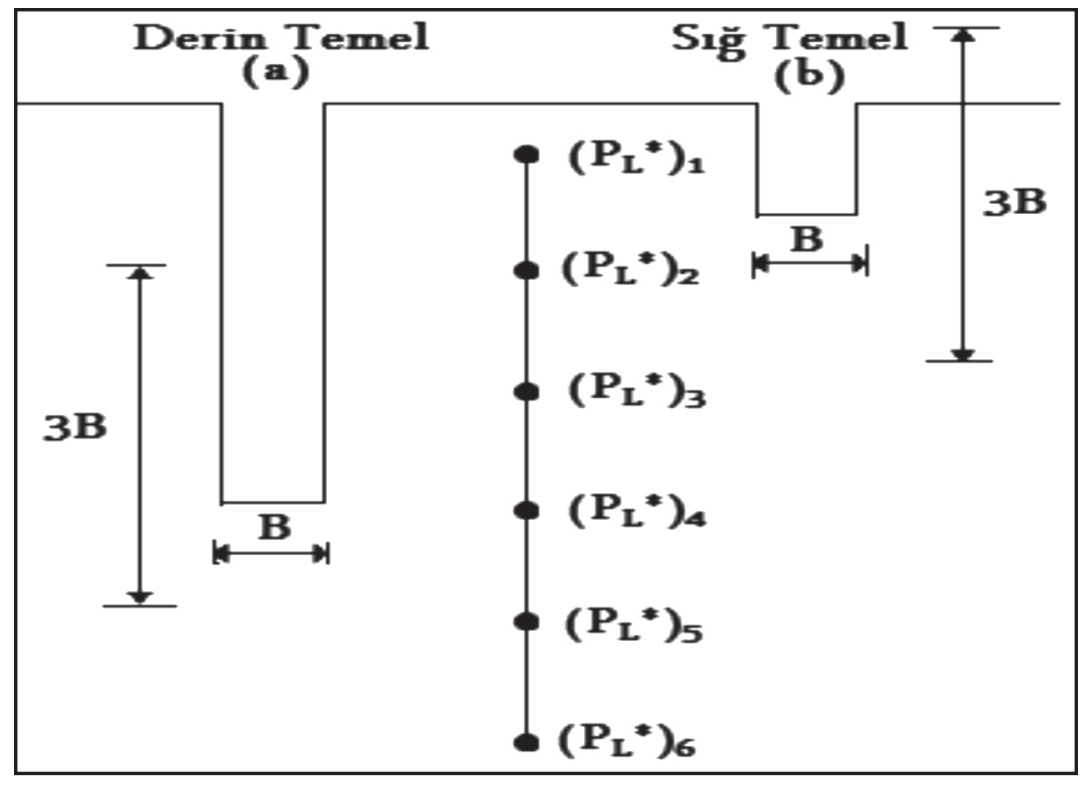

Şekil 18. Temel zemininin taşıma gücünün belirlenmesi için hayali tabakalara bölünmesi.

Figure 18. Division of the foundation soil for the assessment of bearing capacity.

$$
\mathrm{P}_{1 \mathrm{c}} *=\left(\mathrm{P}_{11} \mathrm{xP}_{12} \mathrm{xP}_{13}\right)^{1 / 3}
$$

$\mathrm{P}_{11}^{*}$ : Temel taban seviyesinin üstünde, $+3 \mathrm{R}$ ile $+\mathrm{R}$ aralığında tespit edilen net limit basınç değeri

$\mathrm{P}_{12}^{*}$ : Temel taban seviyesinin alt ve üstünde $(+\mathrm{R}$ ile $-\mathrm{R})$ ölçülen net limit basınç değerlerinin geometrik ortalamas1

$\mathrm{P}_{13}{ }^{*}$ : Temel taban seviyesinin altında $-\mathrm{R}$ ile $-3 R$ aralığında ölçülen net limit basınç değerlerinin geometrik ortalaması

Yüzeysel temellerde, $\mathrm{P}_{11}$ * değeri dikkate alınmadan, eşdeğer limit basıncı hesaplanırken, Eşitlik 8 dikkate alınır.

$$
\mathrm{P}_{1 \mathrm{c}}^{*}=\left(\mathrm{P}_{12} * \mathrm{xP}_{13} *\right)^{1 / 2}
$$

Kuloğlu regülatör yerinde SK-1 kuyusunda yapılan presiyometre deformasyon modülü $\left(\mathrm{E}_{\mathrm{M}}\right)$ ve presiyometre net limit basınç $\left(\mathrm{P}_{1}^{*}\right)$ değerleri sondaj loguna işlendikten sonra taşıma gücü hesaplamaları için temel tabanı seviyesinden sonrası $\mathrm{R}=\mathrm{B} / 2$ şeklinde zonlanarak aşağıdaki gibi gruplandırmalar yapılmıştır.

$\mathrm{P}_{12}$ *: Temel taban seviyesinin alt ve üstünde, $+\mathrm{R}$ ile $-\mathrm{R}$ aralığında tespit edilen net limit basınç değerlerinin geometrik ortalamasıdır. Örneğimizde bu aralığa düşen değerler: 29.0 kgf/ $\mathrm{cm}^{2}, 19.2 \mathrm{kgf} / \mathrm{cm}^{2}, 34.9 \mathrm{kgf} / \mathrm{cm}^{2}, 37.9 \mathrm{kgf} / \mathrm{cm}^{2}$ ve $23.2 \mathrm{kgf} / \mathrm{cm}^{2}$ dir

$\mathrm{P}_{13}^{*}$ : Temel taban seviyesinin altında $-\mathrm{R}$ ile $-3 R$ aralığında tespit edilen net limit basınç değerleri geometrik ortalamasıdır. Örneğimizde bu aralığa düşen değerler:4 $4.2 \mathrm{kgf} / \mathrm{cm}^{2}, 45.5$ $\mathrm{kgf} / \mathrm{cm}^{2}$ ve $15.52 \mathrm{kgf} / \mathrm{cm}^{2}$ ' dir. 
Kayabaşı

$$
\mathrm{P}_{12}{ }^{*}=(29.0 \times 19.2 \times 34.9 \times 37.9 \times 23.2)^{1 / 5}=
$$
$26.13 \mathrm{kgf} / \mathrm{cm}^{2}$

$$
\mathrm{P}_{13} *=(44.2 \times 45.5 \times 15.52)^{1 / 3}=31.49 \mathrm{kgf} / \mathrm{cm}^{2}
$$

Eşitlik 8'e değerlerin konmasıyla net eşdeğer limit basinç $\left(\mathrm{P}_{\mathrm{lc}}{ }^{*}\right)$ bulunur:

$\mathrm{P}_{\mathrm{lc}}^{*}=(26.13 * 31.49)^{1 / 2}=28.69 \mathrm{kgf} / \mathrm{cm}^{2}$

Tesis yerini oluşturan alüvyon, taneli ve sıkı olarak tanımlanmıştır. Bu tanımlamaya göre Çizelge 6'dan k-değerlerini tanımlayan eşitlik seçilmiştir (kare temel için $\mathrm{B} / \mathrm{L}=1$ 'dir).

$\mathrm{k}=1.2+0.4 \mathrm{~B} / \mathrm{L}=1.2+0.4 * 1=1.6$ olarak bulunur.

İzin verilebilir taşıma gücü;

$$
\begin{aligned}
& q_{a}=\frac{q_{u}}{3}=\frac{1}{3}\left[D f x \gamma_{n}+k x P_{l c}\right] \\
& q_{a}=\frac{1}{3}[3 x 1.83+1.6 \times 286.9] \\
& q_{a}=154.84 \text { tonf } / \mathrm{m}^{2}
\end{aligned}
$$

\section{KULOĞLU REGÜLATÖR YERİNDE PRESIYYOMETRE DENEY SONUÇLARIYLA OTURMA MIKTARININ TAHMINI}

Baquelin vd. (1978) tarafindan, temel taban zeminindeki oturmaları farklı özellikte olan zeminler için değişik yöntemler önerilmiştir. $\mathrm{Bu}$ yöntemler: 1) Homojen zeminler içerisindeki sığ temellerde oturma, 2) heterojen zeminlerde oturma, 3) yüksek derecede değişken zeminlerde oturma (iki tabaka sistemi, daha katı tabakalar arasında gevşek yapılı sıkışabilir bir tabakanın bulunması durumu). Kuloğlu regülatör yerinde SK-1 ve SK-2 kuyularında geçilen alüvyonda ölçülen Menard presiyometre modül değerlerinde fazla değişkenlik tespit edilememiştir. Bununla birlikte oturma analizlerinde zemin heterojen ve homojen olarak kabul edilerek analizler yapılmıştır.

\section{Temel tabanı zemininin heterojen olması durumu için oturma analizi}

Presiyometre deneyinden elde edilen $\mathrm{E}_{\mathrm{M}}$ değerleri kullanılarak bir yapıda meydana gelebilecek oturmalar hesaplanabilir. Şekil 19'da görüldüğü gibi temel zemini $\mathrm{R}=\mathrm{B} / 2$ kalınlığında olacak şekilde dilimlere ayrılmıştır. Her dilim içerisinde ölçülen Menard modülü $\left(E_{M}\right)$ okumalarının harmonik ortalaması alınarak, o dilimi temsil edecek eşdeğer deformasyon modülü değeri $\left(E_{\mathrm{i}}\right)$ hesaplanır. Diğer bir anlatımla, 1. dilim içerisinde alınan okumalar $\mathrm{E}_{1}$, $\mathrm{E}_{2}, \mathrm{E}_{3}$ ise 1. dilimin $\mathrm{E}_{\mathrm{i}}$ değeri aşağıdaki eşitlikten hesaplanır.

$$
\mathrm{E}_{\mathrm{i}}=3 /\left(1 / \mathrm{E}_{1}+1 / \mathrm{E}_{2}+1 / \mathrm{E}_{3}\right)
$$

Her dilim için benzer işlemler yapılarak her tabakanın $\mathrm{E}_{\mathrm{i}}$ değeri hesaplanır. Deviatorik gerilme bölgesi eşdeğer Menard modülü değeri $\left(E_{d}\right)$ ve hacimsel gerilme bölgesi eşdeğer presiyometre modülü değeri $\left(\mathrm{E}_{\mathrm{c}}\right)$ 'yi hesaplamak için aşağıdaki eşitlikler önerilmiştir:

$$
\mathrm{E}_{\mathrm{c}}=\mathrm{E}_{\mathrm{i}}
$$


$E_{d}=4 / \frac{1}{E_{1}}+\frac{1}{0.85 E_{2}}+\frac{1}{E_{3 / 4 / 5}}+\frac{1}{2.5 E_{6 / 7 / 8}}+\frac{1}{2.5 E_{9 / 16}}$

Ep/q'nun anlamı p ve q dilimini de kapsayan aralığa düşen $\mathrm{E}_{\mathrm{i}}$ 'lerin harmonik ortalamasıdır.

Kuloğlu regülatör yerinde temel kazı derinliği $\mathrm{D}_{\mathrm{f}}=3 \mathrm{~m}$, regülatörün kısa kenarı $\mathrm{B}=$ $24 \mathrm{~m}$ olarak projelendirilmiştir. $\mathrm{R}=\mathrm{B} / 2=12 \mathrm{~m}$ alınması durumunda 16 nolu dilime kadar olan derinliğin 195 m olması gerekmektedir. Eşitlik 12'nin tam olarak uygulanabilmesi için $195 \mathrm{~m}$ derinliğe kadar Menard modülü değerlerimizin olması gerekir.

Eğer $\mathrm{E}_{9}$ ile $\mathrm{E}_{16}$ 'ya kadar olan aralıktaki modül değerleri herhangi bir nedenle ölçülememiş ise aşağıdaki eşitlik önerilmiştir (Gambin ve Rousseau, 1998).

$$
E_{d}=\frac{3.6}{\frac{1}{E_{1}}-\frac{1}{0.85 E_{2}}-\frac{1}{E_{3 / 4 / 5}}-\frac{1}{2.5 E_{6 / 7 / 8}}}
$$

Eşitlik 12'nin tam olarak uygulanabilmesi için $99 \mathrm{~m}$ derinliğe kadar Menard modülü değerlerimizin olması gerekir.

Eğer $\mathrm{E}_{6}$ ile $\mathrm{E}_{8}$ 'e kadarki olan aralıktaki modül değerleri de herhangi bir nedenle ölçülememiş ise aşağıdaki eşitlik önerilmiştir (Gambin ve Rousseau, 1998)

$$
E_{d}=\frac{3.2}{\frac{1}{E_{1}}+\frac{1}{0.85 E_{2}}+\frac{1}{E_{3 / 4 / 5}}}
$$

Eşitlik 13'ün tam olarak uygulanabilmesi için $63 \mathrm{~m}$ derinliğe kadar Menard modülü değerlerimizin olması gerekir.

Heterojen zeminlerde Oturma hesabı için Menard tarafından önerilen formül aşağıdaki gibidir (Baquelin vd., 1978).

$$
S=\frac{2}{9 \cdot E_{\mathrm{d}}} \cdot q_{\text {net }} \cdot B_{0} \cdot\left(\lambda_{d} \frac{B}{B_{0}}\right)^{\alpha}+\frac{\alpha}{9 E_{\mathrm{c}}} \cdot q_{\text {net }} \cdot \lambda_{c . B}
$$

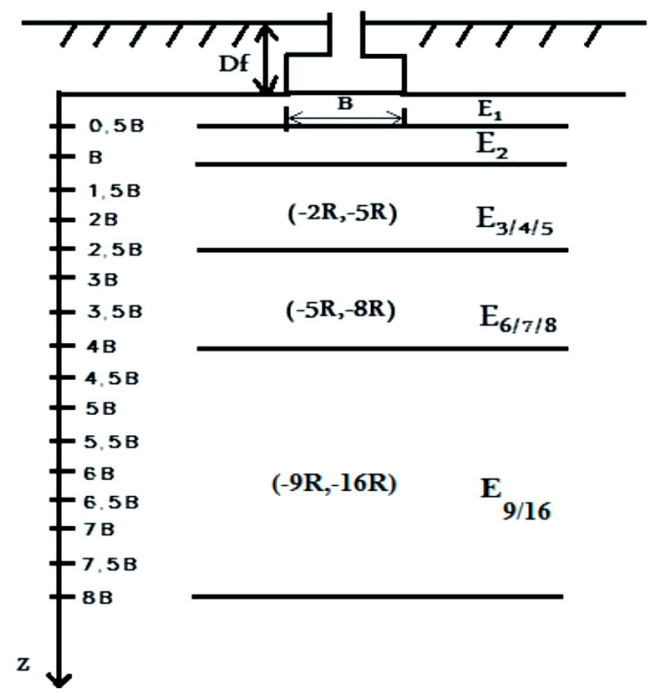

Şekil 19. Temel zemininin oturma miktarının belirlenmesi için hayali tabakalara bölünmesi.

Figure 19. Division of the foundation soil for the assessment of settlement capacity. 
Kayabaşı

$\mathrm{E}_{\mathrm{d}}$ : Deviatör gerilme bölgesi eşdeğer presiyometre modülü değeri

$\mathrm{E}_{\mathrm{c}}$ : Hacımsal gerilme bölgesi eşdeğer presiyometre modülü değeri

$\mathrm{q}_{\text {net }}: \mathrm{q} \mathrm{q}_{\mathrm{o}}=\mathrm{q}-\gamma_{\mathrm{n}} * \mathrm{D}_{\mathrm{f}}=$ Temel taban seviyesindeki net temel taban basinc1

q:Yapıdan zemine gelen temel taban basinc1 (Sürşarj yükü) alınır)

$\mathrm{B}_{\mathrm{o}}$ : Referans genişlik (genellikle $60 \mathrm{~cm}$

$\mathrm{B}$ : Temelin genişliği

$\alpha$ : Zemin cinsine ve $\mathrm{E}_{\mathrm{M}} / \mathrm{P}_{\mathrm{L}}$ * oranına bağlı reolojik faktör (Çizelge 8) $\lambda_{\mathrm{d}}, \lambda_{\mathrm{c}}$ : Temelin L/B oranına bağlı olan şekil faktörü (Çizelge 9)

$\gamma:$ doğal birim hacim ağırlık

$\mathrm{D}_{\mathrm{f}}$ : Temel derinliği

Bu eşitliğin ilk bölümü gerilmenin deviatorik bileşenin etkisinde hacim değişimi olmaksızın kayma deformasyonu sonucu meydana gelen (shear veya distortion deformation) oturmay1, ikinci bölüm ise gerilmenin küresel bileșeninin etkisiyle zemindeki hacim azalması sonucu meydana gelen (volumetrik veya konsolidasyon deformasyonu) oturmayı gösterir (Şekil 20).

Çizelge 8. Değişik zeminler için reolojik faktör $(\alpha)$ değerleri.

Table 8. The values of rheological factor $(\alpha)$ for various soils.

\begin{tabular}{|c|c|c|c|c|c|c|c|c|}
\hline \multirow{2}{*}{$\frac{\text { ZEMİN CINSII }}{\mathbf{E}_{\mathrm{M}} / \mathbf{P}_{\mathbf{L}}^{*}}$} & \multicolumn{2}{|c|}{ KİL } & \multicolumn{2}{|c|}{ SILT } & \multicolumn{2}{|c|}{ KUM } & \multicolumn{2}{|c|}{ KUM VE ÇAKIL } \\
\hline & $\mathbf{E}_{\mathrm{M}} / \mathbf{P}_{\mathrm{L}}$ & $\alpha$ & $\mathbf{E}_{\mathrm{M}} / \mathbf{P}_{\mathrm{L}}{ }^{*}$ & $\alpha$ & $\mathbf{E}_{\mathrm{M}} / \mathbf{P}_{\mathrm{L}}{ }^{*}$ & $\alpha$ & $\mathbf{E}_{\mathbf{M}} / \mathbf{P}_{\mathrm{L}}^{*}$ & $\alpha$ \\
\hline Aşırı konsolide & $>16$ & 1 & $>14$ & $2 / 3$ & $>12$ & $1 / 2$ & $>10$ & $1 / 3$ \\
\hline Normal konsolide & $9-16$ & $2 / 3$ & $8-14$ & $1 / 2$ & $7-12$ & $1 / 3$ & $6-10$ & $1 / 4$ \\
\hline Ayrışmış veya yoğrulmuş & $7-9$ & $1 / 2$ & & $1 / 2$ & & $1 / 3$ & & $1 / 4$ \\
\hline
\end{tabular}

Çizelge 9. Temeller için şekil faktörleri $\left(\boldsymbol{\lambda}_{\mathrm{d}}, \boldsymbol{\lambda}_{\mathrm{c}}\right)$.

Tablo 9. The shape factors $\left(\lambda_{d}, \lambda_{c}\right)$ for foundations.

\begin{tabular}{|c|c|c|c|c|c|c|}
\hline \multirow[t]{2}{*}{$\mathrm{L} / \mathrm{B}$} & \multicolumn{2}{|c|}{1} & \multirow[t]{2}{*}{2} & \multirow[t]{2}{*}{3} & \multirow[t]{2}{*}{5} & \multirow[t]{2}{*}{20} \\
\hline & Daire & Kare & & & & \\
\hline$\lambda_{d}$ & 1.0 & 1.12 & 1.53 & 1.78 & 2.14 & 2.65 \\
\hline$\lambda_{c}$ & 1.0 & 1.10 & 1.20 & 1.30 & 1.40 & 1.50 \\
\hline
\end{tabular}




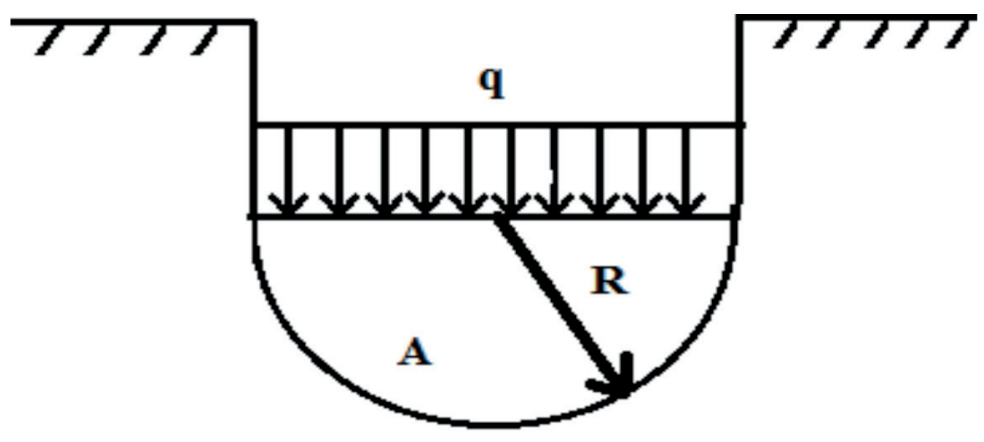

B

Şekil 20. Küresel gerilme bölgesi A ve deviatorik gerilme bölgesi B.

Figure 20. Spherical stress zone A and deviatoric stress zone B.

Kuloğlu regülatör yerinde açılan SK-1 kuyusu içerisinde temel kazısı seviyesinden sonra B/2 = 12 m'lik zonlar oluşturulursa, kuyu derinliğinin 20 m'den fazla olmaması nedeniyle $\mathrm{E}_{1}$ ve $\mathrm{E}_{2}$ bölgesi için verilerin olduğu, $\mathrm{E}_{3 / 4 / 5}$, $\mathrm{E}_{6 / 7 / 8}$ ve $\mathrm{E}_{9 / 16}$ bölgesi için kuyu derinliğinin yeterli olmadığı görülür. $\mathrm{Bu}$ sorunun aşılması için Gambin ve Rousseau (1998), E 2 bölgesine düşen Menard presiyometre modülleri harmonik ortalamasının, $\mathrm{E}_{3 / 4 / 5}$ olarak da kullanılabildiği Eşitlik 14'ü önermiştir. Sorun böylelikle aşılsa bile bulunan oturma değeri alüvyonun ilk 20 m'si için gerçekçi olacak, daha derin seviyeler için aynı durum söz konusu olamayacaktır.

1.Tabaka:

$5 / \mathrm{E}_{1}=(1 / 145.3)+(1 / 147.0)+(1 / 156.1)+(1 / 26$ $6.1)+(1 / 118.4)$

$$
\mathrm{E}_{1}=155.82 \mathrm{kgf} / \mathrm{cm}^{2}
$$

2.Tabaka:

$3 / \mathrm{E}_{2}=(1 / 253.7)+(1 / 283.1)+(1 / 93.6)$

$\mathrm{E}_{2}=165.23 \mathrm{kgf} / \mathrm{cm}^{2}$

$\mathrm{E}_{3 / 4 / 5}$ değerlerinin olmamas1 nedeniyle $\mathrm{E}_{2}$ değeri eşitlikte $E_{3 / 4 / 5}=165.23 \mathrm{kgf} / \mathrm{cm}^{2}$ olarak kabul edilir.

$$
\begin{aligned}
& \mathrm{E}_{\mathrm{c}}=\mathrm{E}_{1}=15582 \mathrm{kPa} \\
& E_{d}=\frac{1}{\frac{1}{15582}+\frac{1}{0.85 \times 16504}+\frac{1}{16523}} \\
& \mathrm{E}_{\mathrm{d}}=16322 \mathrm{kPa}
\end{aligned}
$$

Reolojik faktörün $(\alpha)$ bulunabilmesi için SK-1 kuyusundaki $\mathrm{E}_{\mathrm{M}}$ ve $\mathrm{P}_{1}^{*}$ değerlerinin aritmetik ortalamalarının hesaplanması gerekir.

$$
\alpha=1 / 4\left(\text { kil ile } \mathrm{E}_{\text {Mort }} / \mathrm{P}_{\text {lort }} *=183 / 31.2=6\right.
$$
(Çizelge 8)

$$
\mathrm{L} / \mathrm{B}=1 \text { için }
$$

$\lambda_{\mathrm{d}} \approx 1.12$ (Çizelge 9)

$\lambda_{\mathrm{c}} \approx 1.10$ (Çizelge 9)

$\mathrm{D}_{\mathrm{f}} / \mathrm{B}=0.125$ değerine göre Şekil 21'den oturma miktarında \%1 7.5 artış yapılır. 
Kayabaşı

Değerler eşitlik 14'te yerine konularak oturma miktarı hesaplanır.

$$
{ }_{\text {net }}=\mathrm{q}-\gamma_{\mathrm{n}}{ }^{*} \mathrm{D}_{\mathrm{f}}=313.82-3 * 17.94=260 \mathrm{kPa}
$$$$
\frac{S}{1.175}=\frac{2}{9 \times 16322} \times 260 \times 0.6 \times\left(1.12 \frac{24}{0.6}\right)^{1 / 4}
$$$$
+\frac{1}{9 \times 15582} \times 260 \times 1.10 \times 24
$$

$$
\mathrm{S}=0.017 \mathrm{~m}=1.7 \mathrm{~cm}
$$

\section{Temel taban seviyesinin homojen olması durumunda oturma}

Baquelin vd., (1978) temel alanında alınan Menard modülü değerlerinin çok farklılık göstermemesi durumunda homojen zeminlerdeki yapılar için aşağıdaki eşitliği önermiştir:

$s=\frac{2}{9 \cdot E_{M}} \cdot q_{\text {net. }} \cdot B_{0} \cdot\left(\lambda_{d} \frac{B}{B_{0}}\right)^{\alpha}+\frac{\alpha}{9 E_{M}} \cdot q_{\text {net }} \cdot \lambda_{c . B}$

$\mathrm{E}_{\mathrm{M}}$ : Homojen özellik gösteren Menard deformasyon modüllerinin aritmetik ortalamas1

Temel kazı derinliğinin $\mathrm{D}<\mathrm{B}$ olması durumunda, 16 numaralı eşitlikten belirlenen değerin şekil 20'deki grafikten bulunan değer kadar arttırılması gerekmektedir.

Kuloğlu regülatör yerinde presiyometre deneyleriyle belirlenen Menard deformasyon modüllerinin ortalaması $\left(\mathrm{E}_{\mathrm{M}}\right)=183 \mathrm{kgf} / \mathrm{cm}^{2}$ ' dir.

$$
\begin{gathered}
S=\frac{2}{9 \times 18300} \times 260 \times 0.6 \times\left(1.12 \times \frac{24}{0.6}\right)^{1 / 4} \\
+\frac{0.25}{9 \times 18300} \times 260 \times 1.10 \times 24 \\
\mathrm{~s}=0.0154 \mathrm{~m}=1.54 \mathrm{~cm} \text { olarak bulunur. } \\
\mathrm{D}_{\mathrm{f}} / \mathrm{B}=0.125 \text { değerine göre Şekil } 21 \text { 'den }
\end{gathered}
$$
oturma miktarında \%17.5 artış yapılır.

$\mathrm{s}=1.54 * 1.175=1.80 \mathrm{~cm}$ olarak son oturma miktarı belirlenir.

Aşağ1 Aras projesi Kuloğlu HES regülatör yerinde açılan SK-2 kuyusunda da SK-1 kuyusundaki verilerin değerlendirildiği gibi limit basınç ve Menard deformasyon modülleri değerlendirilerek taşıma gücü ve oturma miktarı hesaplanmıştır. SK-1 ve SK-2 kuyularında yapılan presiyometre deney sonuçlarından hesaplanan taşıma gücüyle oturma sonuçları Çizelge 10 'da verilmiştir. Regülatör temelleri radye jeneral temel olarak kabul edilir. Radye jeneral temeller için kumlarda toplam oturma tolerans sinırı $7.5 \mathrm{~cm}$, farklı oturma sinırı ise $3.2 \mathrm{~cm}$ olarak belirlenmiştir ( Kumbasar ve Kip, 1992). Bu değerlendirmeye göre oturmalar tolerans sınırları içerisindedir.

\section{TARTIŞMA VE SONUÇLAR}

Genel anlamdayapıların projelendirilmesinde önerilen Menard presiyometre deneyinin büyük boyutlu baraj regülatör yerlerinde kullanılması uygulamada bazı sorunlara yol açmaktadır. Kuloğlu regülatörünün kısa kenarı $24 \mathrm{~m}$ 


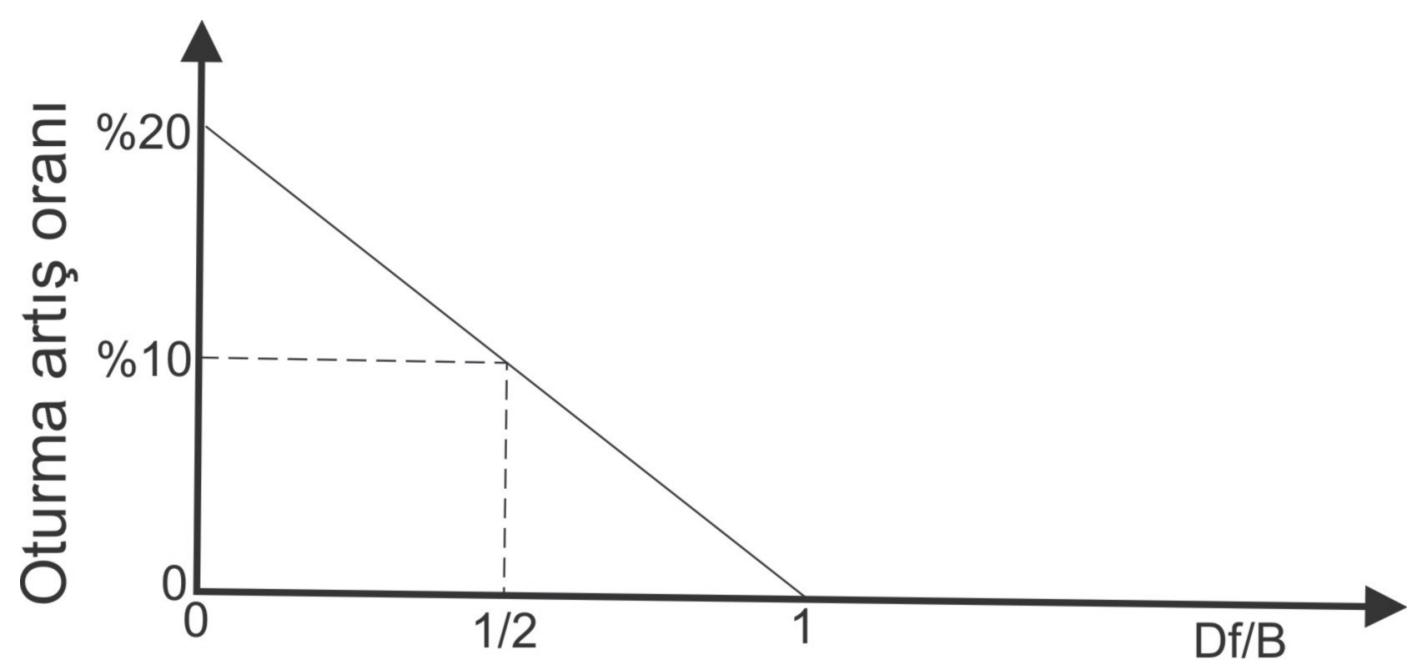

Şekil 21. Oturma artış oranı (D:Temel kazı derinliği, B:Temel kısa kenar uzunluğu).

Figure 21. Settlement increment ratio (D:Foundation excavation depth, B:Foundation width).

olarak projelendirilmiştir. Regülatör yerinde proje yükünün etkisiyle oluşacak oturma miktarının tam olarak belirlenebilmesi için sondaj derinliğinin Eşitlik 11'e göre 196 m olması gerekirken, Eşitlik 12'ye göre 99 m, Eşitlik 13'e göre ise $63 \mathrm{~m}$ olması gerekir. Menard presiyometresi deney hortumunun uzunluğunun $50 \mathrm{~m}$ standart olarak satışta olması ve deney hortumunun $120 \mathrm{~m}$ derinliğe kadar uzatılabileceğinin belirtilmesine rağmen Menard presiyometre cihazıyla en fazla kaç metre derinliğe kadar deney yapılabileceği belirsizdir. Konuya ilişkin literatürde veya ilgili standartlarda bir açıklama yoktur.
Kuloğlu HES regülatör yerindeki projelendirme $\mathrm{D}_{\mathrm{f}} / \mathrm{B}$ değerinin oldukça düşük olması nedeniyle "sığ temel" sınıfi olarak dikkate alınmıştır. Eşitlik 8'e göre, taşıma gücünün belirlenebilmesi için limit basınç değerlerinin 36 m'ye kadar belirlenmesi $(-3 \mathrm{R}=36 \mathrm{~m})$ gereklidir. Sondaj kuyu derinlikleri kuyu genişlemesi ve çökmesi nedeniyle limit basınç değerleri SK-1 kuyusunda 20 m'ye kadar, SK-2 kuyusunda 24 m'ye kadar alınabilmiştir. Bu aralıklarda alınan değerlerle taşıma gücü hesaplamaları yapılmıştır.

Coduto (1999)'a göre net proje yükünün oluşturacağı gerilim değerinin, \%10 değerine kadar azaldığı derinliğin, temelin kısa kenarı uzunluğunun

Çizelge 10. Menard presiyometre deney sonuçları kullanılarak elde edilen oturma ve taşıma gücü değerleri.

Table 10. The bearing capacity and settlement values obtained by using the results of Menard pressuremeter test.

\begin{tabular}{ccccccc}
\hline Kuyu No & \multicolumn{2}{c}{$\begin{array}{c}\text { Nihai taşıma gücü, } \\
\text { qu, }\left(\mathrm{kgf} / \mathrm{cm}^{2}\right)\end{array}$} & \multicolumn{2}{c}{$\begin{array}{c}\text { İzin verilebilir } \\
\text { taşıma gücü, qa }\left(\mathrm{kgf} / \mathrm{cm}^{2}\right)\end{array}$} & $\begin{array}{c}\text { Heterojen yöntemle } \\
\text { oturma }(\mathrm{cm})\end{array}$ & $\begin{array}{c}\text { Homojen yöntemle } \\
\text { oturma } \\
(\mathrm{cm})\end{array}$ \\
& Sürsarjlı & Sürsarjsız & Sürsarjlı & Sürsarjsı & 1.70 & 1.80 \\
SK-1 & 46.48 & 45.94 & 15.86 & 15.31 & 3.31 & 1.88 \\
SK-2 & 47.77 & 47.22 & 16.29 & 15.74 & 31 & \\
\hline
\end{tabular}


Kayabaşı

iki katı kadarlık derinliğe eşit olduğunu ifade eder. Regülatör temelinin kısa kenarı 24 m olduğu için net proje yükünün $\% 10$ değerine sönümlendiği derinlik yaklaşık 48 m olmalıdır. Kuloğlu regülatör yerinin kare bir temel olması ve proje net yükünün $\left(\mathrm{q}_{\text {net }}\right)=260$ kPa'ya eşit olmasının kabulu ile, uniform bir şekilde yüklenmiş dikdörtgen bir alanın orta noktasındaki gerilim dağılımını hesaplarsak net gerilimin 20. metrede, 111.18 kPa'ya, 24 . metrede ise $87.36 \mathrm{kPa}$ 'ya düştüğünü ve proje net yükünün 24 metre derinlikte \% 10 değerine kadar sönümlenmediğini görürüz. Proje net yükünün $45 \mathrm{~m}$ derinlikte $39 \mathrm{kPa}$ 'ya, 49 metrede ise 19 kPa’ya düştügünü görürüz. Bu değerlendirmelerin 1şığında 20-24 m'ye kadar olan verilerin yetersiz kaldığı açıkca görülecektir. Daha derinlerde kuyunun devamlı genişlemesi veya çökmesi (kendini tutamamas1) sonucu presiyometre deneyi yapılamamıştır. Bu nedenle 24 m'ye kadar yapılan presiyometre taşıma gücü ve oturma analizleri yetersiz kalmaktadır. Çünkü gerilme dağılımının 20 m'den daha derinlerde de devam etmesi söz konusudur. Sonuçta bu durumlar dikkate alınarak regülatör yeri için alüvyon zeminin tamamının kaldırılması önerilmiştir.

İri taneli zeminlerde beklenilen oturma türü anlık oturmadır. Kuloğlu regülatör yerinde hesaplanan Menard presiyometre deneyi oturma sonuçları ile karşılaştırmak amacı ile, Harr (1966) tarafından geliştirilen anlık oturma hesaplaması yapılmıştır (Eşitlik 17).

$$
S_{i}=q x B x\left(\frac{1-v}{E_{\mathrm{u}}}\right) x l_{s}
$$

$$
\mathrm{S}_{\mathrm{i}} \text { : Ani oturma }
$$

q : Temel alanındaki net taban basıncı (260 $\mathrm{kPa})$ $v$ : Poisson oran1 (0.33)

B : En küçük yanal boyut (Genişlik veya çap) $(24 \mathrm{~m})$

$\mathrm{E}_{\mathrm{u}}$ : Drenajsiz elastisite (young) modülü (Bu çalışmada drenajsız elastisite modülü sıkı kum/çakıl için $150 \mathrm{MN} / \mathrm{m}^{2}$ olarak Özüdoğru vd. (1988)'den alınmıştır).

$\mathrm{I}_{\mathrm{s}}$ : Temel alanının şekli ve rijitliğine bağlı tesir faktörü. Tesir faktörü, $B=24 \mathrm{~m}$ ve $\mathrm{L}=24$ $\mathrm{m}$ için kare ve rijit bir temel için 0.82 olarak Özüdoğru vd. (1988)'den alınmıştır.

$$
S_{i}=260 * 24 * \frac{1-0.33}{150000} * 0.82=0.0229 \mathrm{~m}=2.29 \mathrm{~cm}
$$

Granüler zeminlerde yapılan presiyometre deneyinden belirlenen oturma değerleri ile anlık oturma değerleri yakınlık göstermektedir.

Menard presiyometre deneyinin sağlıklı yapılabilmesi için bazı önerilerde bulunulmuştur:

- Her sonda lastiği değişimininde, yeni proje başlangıcında veya her on deney sonrası lastiğin esnemesi göz önüne alınarak, periyodik aralıklarla kalibrasyonlar yeniden yapılmalıdir.

- Bir başka presiyometreye ait kalibrasyon değerleri kullanılmamalıdır.

- Kullanılacak sonda çapına uygun sondaj kuyusu açılmalıdır.

- Sondaj aç1lırken bentonit veya benzeri maddeler kullanılmamalıdır. Bentonit veya benzeri maddelerin kullanılması sonucunda presiyometre deneyinin yapılacağı zeminin elastik özellikleri değişmekte bu ise yanlış sonuçlara yol açmaktadır. 
- Deney sirasında sondadaki merkez ve muhafaza hücrelerindeki basınç dengesini sağlayan diferansiyel basınç ayarına dikkat edilmelidir.

- Mümkünse, her 1 metrede bir deney yapılmalıdır. Bununla birlikte deney yapılan birimin özelliklerinin değişmemesi durumunda deney aralığı açılabilir veya çok değişim gösteren birimlerde deney sayısı artır1labilir.

- Projelendirilen yap1 net yükünün sönümlendiği derinliğe kadar sondaj açılarak presiyometre deneyleri yapılmalıdır.

\section{KATKI BELIRTME}

$\mathrm{Bu}$ çalışmada, Elektrik İşleri Etüt İdaresi'nin projelendirdiği Aşağı Aras Havzası HES Projelerinden birisi olan Kuloğlu HES projesi regülatör yerinde açılan iki adet kuyuda yapılan presiyometre deney verileri kullanılmıştır. Yazar, Jeoloji mühendisleri Yaşar Alkılıç'a, Ali Kaya'ya, Necmettin Gürsoy'a, Osman Ceylan'a, Cemil Demirer'e ve Ertuğrul Kanmaz'a teşekkür eder.

\section{KAYNAKLAR}

Agan, C., 2011. Investigation of bearing capacity changes of different clays by using the Menard pressuremeter tests. International Journal of the Physical Sciences, 6 (23), 5454-5461.

Apageo., 2006. Menard Pressuremeter (G Type) operating instructions, 2006 edition.

ASTM (American society for testing and materials)., 1994. Annual book of ASTM Standarts-Section 4, Construction, V. 0408 Soil and Rock; Building Stones. ASTM Publication, 978 p.
Baquelin, F., Jezequel, J.F., Shields, D. H., 1978. The Pressuremeter and Foundation Engineering. Trans Tech Publications, Clausthal-Zellerfeld, Germany, $617 \mathrm{p}$.

Bozbey, İ., Togrol, E., 2009. Correlation of standart penetration test and pressuremeter data:a case study from Istanbul, Turkey. Bulletin of Engineering Geology and the Environment, 69, 505-515.

Centre d'Etudes Mènard, 1971. La mèthode des volumes relatifs. Notice D22-A71.

Coduto, D.P., 1999. Geotechnical Engineering Principles and Practices. Prentice-Hall, USA.

Erdoğan, H., 1980. Zemin ve Kaya Mekaniği Arazi Deneyleri. Mühendislik Jeolojisi Toplantıs1-5.,9-14 Haziran 1980, Yalova Tesisleri, 98 s.

Gambin, M.P., Rousseau, J., 1998. The Menard Pressuremeter Interpretation and application of pressuremeter test results to foundation design. United Kingdom: ISSMFE, $50 \mathrm{p}$.

Hansen, J.B., 1961. The Bearing Capacity of Sand Tested by Loading Circular Plates. 5 th International Conference on Soil Mechanic Foundation. England:Vol 1, 659-664, Paris.

Harr, M.E., 1966. Fundamentals of Theoretical Soil Mechanics. Mc Graw-Hill-New York.

ISRM, 1981. ISRM Suggested Methods: Rock Characterization, Testing and Monitoring. E.T. Brown (ed.); Pergamon Pres, London, 211 p.

Isik, N.S., Ulusay, R., Doyuran, V., 2008. Deformation modulus of heavily jointed-sheared and blocky greywackes by pressuremeter tests: Numerical, experimental and empirical assessments. Eng. Geol., 101, 269-282.

Jézéquel, J.F., Lemėe, E., Saintilan, D., 1974. Exploitation de I2essai pressomètriquenormal par mèthode numèrique. Bulletin de Liaison des Laboratories des Ponts et Chaussèes. No. 69 Janvier-Fèvrier, ref. 1375, 105-114. 
Kayabaşı

Kayabaş1, A., 2012. Prediction of pressuremeter modulus and limit pressure of clayey soils by simple and non linear multiple regression techniques: a case study from Mersin, Turkey. Environmental Earth Science, 66, 2171-2183.

Kayabaşı, A., Gökceoğlu, C., 2012. Taşıma Kapasitesi ve Oturma Miktarının hesaplanmasında Yaygın Kullanılan Yöntemlerin Mersin Arıtma Tesisi Temeli Örneğinde Uygulanması.TMMOB Jeoloji Mühendisleri Odası, Jeoloji Mühendisliği Dergisi, 36 (1), 1-22.

Kumbasar, V., Kip, F., 1992. Zemin Mekaniği Problemleri (5. Baskı). Çağlayan Basımevi, İstanbul, $614 \mathrm{~s}$.

Marnawski M., 2004. The Perfect Menard pressuremeter curve. Archives of Hydroengineering and Environmental Mechanics, 51 (4), 387-402.

Meyerof, G.G., 1963. Some recent research on the bearing capacity of foundations. Canadian Geotechnical Journal, 1 (1), 16-26.
MTA., 2003. 1/500000 ölçekli Türkiye Jeoloji Haritaları; Kars Paftası. Maden Tetkik ve Arama Genel Müdürlüğü, Ankara.

Terzaghi, K., 1943. Theoretical Soil Mechanics. John Wiley\&Sons, New York.

Türk Standartları Enstitüsü (TSE)., 1997. Jeoteknik Tasarım Bölüm 3, Arazi Deneyleri Yardımıyla Tasarım (TS ENV 1997-3, Eurocode 7).

Özüdoğru, K., Tan, O., Aksoy, İ.H., 1988. Çözümlü problemlerler Zemin mekaniği.Birsen Yayınevi, İstanbul, $160 \mathrm{~s}$.

Van Wambeke, A., D'Henricourt, J., 1971. Courbes pressiomètriques inverse. Mèthode d2interpretation de Pessai pressiomètrique. Royal Military School Publication. Bruxelles.

Yağız, S., Akyol, E., Sen, G., 2008. Relationship between the standart penetration test and the pressuremeter test on sandy silty clays:a case study from Denizli. Bulletin of Engineering Geology and the Environment, 67, 405-410. 